\title{
Is Care in the Air?: A Crisis Ethics Case Study of American Airlines' Communication during the COVID-19 Pandemic
}

\author{
Lily V. Hicks \\ West Virginia University, Ivh0001@mix.wvu.edu
}

Follow this and additional works at: https://researchrepository.wvu.edu/etd

Part of the Communication Technology and New Media Commons, Critical and Cultural Studies Commons, Health Communication Commons, International and Intercultural Communication Commons, Interpersonal and Small Group Communication Commons, Journalism Studies Commons, Mass Communication Commons, Organizational Communication Commons, Public Relations and Advertising Commons, Social Influence and Political Communication Commons, and the Social Media Commons

\section{Recommended Citation}

Hicks, Lily V., "Is Care in the Air?: A Crisis Ethics Case Study of American Airlines' Communication during the COVID-19 Pandemic" (2021). Graduate Theses, Dissertations, and Problem Reports. 8341.

https://researchrepository.wvu.edu/etd/8341

This Thesis is protected by copyright and/or related rights. It has been brought to you by the The Research Repository @ WVU with permission from the rights-holder(s). You are free to use this Thesis in any way that is permitted by the copyright and related rights legislation that applies to your use. For other uses you must obtain permission from the rights-holder(s) directly, unless additional rights are indicated by a Creative Commons license in the record and/ or on the work itself. This Thesis has been accepted for inclusion in WVU Graduate Theses, Dissertations, and Problem Reports collection by an authorized administrator of The Research Repository @ WVU. For more information, please contact researchrepository@mail.wvu.edu. 


\section{Is Care in the Air?: A Crisis Ethics Case Study of American Airlines' Communication during the COVID-19 Pandemic}

Lily V. Hicks

Follow this and additional works at: https://researchrepository.wvu.edu/etd

Part of the Communication Technology and New Media Commons, Critical and Cultural Studies Commons, Health Communication Commons, International and Intercultural Communication Commons, Interpersonal and Small Group Communication Commons, Journalism Studies Commons, Mass Communication Commons, Organizational Communication Commons, Public Relations and Advertising Commons, Social Influence and Political Communication Commons, and the Social Media Commons 
Is Care in the Air?: A Crisis Ethics Case Study of American Airlines' Communication during the COVID-19 Pandemic

\title{
Lily Hicks
}

Thesis submitted to the Reed College of Media

at West Virginia University

in partial fulfillment of the requirements for the degree of

Master of Science in

Journalism

\author{
Julia Fraustino, Ph.D., Chair \\ Steve Urbanski, Ph.D. \\ Jennifer Harker, Ph.D. \\ Katie Kang, Ph.D. \\ Reed College of Media \\ Morgantown, West Virginia
}

2021

Keywords: crisis communication, crisis coping, crisis management, ethics, emotions, public relations, Applied Model of Care Considerations, Situational Crisis Communication Theory

Copyright 2021 Lily Hicks 


\begin{abstract}
Is Care in the Air?: A Crisis Ethics Case Study of American Airlines' Communication during the COVID-19 Pandemic
\end{abstract}

\title{
Lily Hicks
}

This research proposes a qualitative case study of American Airlines' communication during the first month of the COVID-19 global pandemic. Data from the airline's press releases along with its tweets and a sample of organizational responses to those tweets are offered for proposed analysis using the lenses of Situational Crisis Communication Theory, the Applied Model of Care Considerations, and the body of crisis literature on audience coping and emotions during crises. This in-depth look at a unique communication phenomenon will be a fundamental step in examining how airline communication exhibits ethics or lack thereof and is related to people's emotions and their ability to cope. This research is valuable because there is relatively minimal crisis communication research from a public relations standpoint concerning emotion and ethics, as well as a need for more robust airline crisis communication research. This is timely and relevant research because the COVID-19 global pandemic remains ongoing and disruptive to lives and livelihoods nationally and globally. This work will be grounded in crisis communication, public relations, and ethics research. Topics such as crisis and crisis management will be addressed. Importantly, this research will use the theoretical lens of the Applied Model of Care Considerations and Situational Crisis Communication Theory. To investigate how, if at all, American Airlines ethically communicated to their publics with visible attention to emotional health and wellbeing, this work will use Robert Yin's (2018) social science qualitative case study approach. 


\section{Table of Contents}

Chapter 1: Introduction and Case Background .....................................Page 1

Chapter 2: Literature Review.......................................................Page 9

Research Questions......................................................................................................Page 37

Chapter 3: Methods...........................................................................................................Page 38

Chapter 4: Results..................................................................Page 49

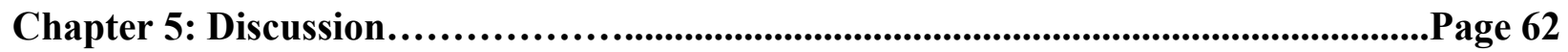

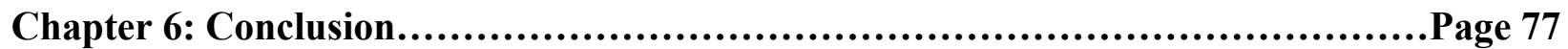

References............................................................................ 79 


\section{Chapter 1: Introduction and Case Background}

Limiting travel, infecting millions globally, and deterring people from leaving their homes, the novel coronavirus SARS-CoV-2, which causes the disease COVID-19, has taken over people's minds and lives around the world (CDC, 2020). Accordingly, the travel industry is suffering greatly. The virus created a public health crisis that is considered a global pandemic by the World Health Organization and the U. S. Centers for Disease Control and Prevention. COVID-19 has changed the way Americans conduct their lives in more ways than oneincluding air travel. The various government sanctions on travel and (necessary) public health guidelines advising against it or diminishing capacity when it is offered have compounded issues for airlines and potential passengers. This research will use the case study method to investigate American Airline's crisis response and the extent to which communication efforts during the first month of this pandemic reflected care-based ethics and a commitment to passengers' emotional wellbeing. With a general lack of airline crisis communication research focusing on ethics from a public relations perspective, this work is important for starting to fill crisis ethics research gaps that are theoretically grounded and practically relevant to the wellbeing of airline publics (and, by extension, airlines' sustainability).

To investigate these ideas, this work is grounded in crisis communication, public relations, and ethics research. Topics such as crisis and crisis management will be addressed. Importantly, this research will use the theoretical lens of the Applied Model of Care Considerations and Situational Crisis Communication Theory to analyze American Airlines' communication efforts. 
American Airlines was chosen for study because of its crisis history. Statistically, aviation fatality and accident rates are on the decline (Fairbanks \& Grabell, 2004). This can be attributed to better equipment, technological advances, and better aviation training (Boeing, 2020). Yet, American Airlines has been dealing with crises since 1943 (American Airlines, 2020). Because the company has a history of experiencing various crisis types, whether it be terrorist attacks or natural disasters, one might assume that they would have been able to apply previous crisis learning to conduct ethical communication with passengers in new crisis settings. However, anecdotal evidence and an informal scan of publics' social media post point otherwise for the airline's COVID-19 communication efforts. This opens questions and possibilities for the current work. Thus, this proposal will explore the extent to which American Airlines' communication during the first month of the COVID-19 pandemic in the United States reflects the theoretical propositions and best practices found in foundational research and literature to formulate ethical and compassionate crisis communication with their publics in the publics' time of need.

To gain perspective, this work will be a fundamental step in examining how a particular airline communication exhibited ethics, or lack thereof, and is related to publics' expressed emotions and their ability to cope. If major organizations ignore or push aside publics' emotions and communicate unethically in connection to their operations and public services is doing an injustice to a large percentage of their customer base and to the profession as a whole. Additionally, as is noted below, crisis communication research is often focused on protecting the reputation and wellbeing of the organization, to the diminishment of the emotions and wellbeing of those affected by the crisis (Liu \& Fraustino, 2014). While the purpose of this research is not to create an in-depth and applied airline crisis communication plan or provide medical 
background on why caring about customers emotional health is important, it will explore an area of crisis communication that is seldom researched and written about, as well as provide findings to future airline crisis communication researchers, in hopes that eventually the subject of ethical airline crisis communication becomes one of importance. To fill these research gaps, this proposed work will take a deep dive into a case that shows how important ethics and ethical communication is in airline communication. In doing so, this thesis will apply and critique tenets of both situational crisis communication theory (e.g., Coombs, 2007) and the applied model of care considerations (Fraustino \& Kennedy, 2019) to add to the scholarly literature. It will also give practical recommendations for ethical considerations in airline crisis communication. Below, a case background provides context on American Airlines and their COVID-19 response.

\section{Case Background}

In 1926, Charles Lindbergh flew the first American Airlines flight, then known as American Airways - carrying U.S. mail from St. Louis, Missouri, to Chicago, Illinois (American Airlines, 2020). After carrying mail for a few years, the airline expanded to a DC-3, a designation allowing transportation of passengers and their baggage. The first passenger flights operated between New York and Chicago. Previously, American Airlines relied on mail transport to make a profit. The DC-3 changed this, and American Airlines was on its way to becoming a major airline (Singh, 2019). In 1945, the airline began to offer its first transatlantic flights. In addition to being one of the first to work with airline manufacturers to create shorter flights, American Airlines also created the first "Stewardess College" in Dallas, making it the first airline to offer official flight attendant training (Fien, 2013). After this, the airline company dabbled in the stock exchange, offered its first coast-to-coast nonstop jet service, and by May 1982, stockholders approved the steps needed to form a new holding company, AMR 
Corporation, that became the parent company of what is now American Airlines, Inc (American Airlines, 2020).

This stream of growth and successes took American Airlines to 2001, when the company bought Trans World Airlines and became the United States' largest commercial airline, as well as one of the most profitable airlines in the world. Then, tragedy struck. On September 11, 2001, two American Airlines flights, Flight 11 and Flight 77, were hijacked and flown into the World Trade Center buildings in New York City. American Airlines lost the lives of 23 people in their organizational family, including pilots, flight attendants, and family members, in the events surrounding Flights 11 and 77 (American Airlines, 2020). This event changed air travel for the entire world. It also cost many airlines a considerable amount of money and several declared bankruptcies, but the behemoth American Airlines recovered and continues to operate as a top airline at the time of this study. With decades of successes and challenges, one might assume that American Airlines learned from their crises and adverse events, through which ethical communication with publics is key to any organization's survival (Austin \& Jin, 2015).

Yet, on February 11, 2020, the World Health Organization announced that SARS-CoV-2, the virus that causes the disease COVID-19 (named as such based on the novel coronavirus of 2019), had officially launched a global pandemic. In the first month of the pandemic, stay at home orders were issued, businesses closed, and misinformation was spread (Majumder, 2020). Leaders were frantically trying to track cases. As with other outbreaks, early estimation of epidemic parameters during the first month of the COVID-19 epidemic was critical to predict the epidemic trajectory and inform decision making (Pollett, 2020).

In May 2020, just over a year after the pandemic launched, despite fragmented international efforts to contain the spread, SARS-CoV2 had spread to 213 countries, resulting in 
more than 5 million cases and deaths approaching 400,000 since its formal identification in Wuhan China in December 2019 (Hiscott, 2020). Those numbers have since continued to rise. The CDC saw that the confirmed and suspected case numbers were rising, and in an effort to slow spread, announced various travel bans and travel restrictions in the early months of 2020 .

In June 2020, four short months after the global pandemic was declared, American Airlines released a press release that stated the company planned to resume about 40 percent of its schedule from July 2019 in July 2020 (American Airlines, 2020). By August 2020, the airline would fly about $55 \%$ of its domestic schedule and $20 \%$ of its international schedule. International service had returned from Dallas-Fort Worth to Amsterdam, Paris and Frankfurt. Flights to London had increased at Chicago and New York airports, and from Miami, flights had resumed to Antigua, Guayaquil and Quito. American Airlines then announced that they would no longer be social distancing on flights, as they had been blocking middle seats since April 2020, but that passengers should certify that they've been symptom and coronavirus free for 14 days prior to their flight (American Airlines, 2020). U. S. Centers for Disease Control Director Robert Redfield stated in an interview in June 2020, after American Airlines announced that they were filling middle seats, that he did not think the airline was sending the right message to Americans amid a pandemic and registered substantial disappointment in the airline (CNBC, 2020).

According to The New York Times, as of February 18, 2021, the United States reported more than $27.9+$ million cases of the virus, with 492,738 deaths. Globally, there were more than 110.2 million cases reported and more than 2.4 million deaths in that timeframe. Over a year later, on May 8, 2021, the death toll has reached 3.7 million. Also, at that time, although vaccines were currently available, demand remained higher than supply, and between limited supply and 
the complex landscape of risk perceptions, medical histories, and vaccine hesitancy, it would take some time for the world to be vaccinated.

\section{American Airlines vs Coronavirus}

At the beginning of the pandemic, it appeared that airlines were simply trying to survive this new travel crisis, while many people were still under the impression that the virus would pass quickly, and activities would go back to normal. Trouble arose, however, when government officials started trying to track where people had been, where they were coming from and going to, and how the virus was traveling through the United States and the world, so that they could try to pinpoint exact locations that the virus might have been coming from. Airlines fought back (Aratani, Sun \& Stein, 2020, para. 3), claiming that the data was not being used for virus tracking purposes, saying

government officials have said they need the data so they can warn local authorities about who might have been exposed to the virus. But the airline industry has balked, saying the federal government should instead share information it already collects among different agencies and come up with a system for obtaining the rest.

In summary, airlines did not want to share their data.

A New York Times article (Greenberg, 2020, para. 1) written in March 2020 proclaimed:

For 15 years, the U.S. government has been pressing airlines to prepare for a possible pandemic by collecting passengers' contact information so that publichealth authorities could track down people exposed to a contagious virus. The airlines have repeatedly refused, even this month as the coronavirus proliferated across the United States. Now the country is paying a price. 
Thus, many airlines did not have pandemic protocol in place, which became starkly apparent to travelers and others as the lack of certainty in airline travel increased, frustrations with airline communication mounted, and unsatisfied airline customers headed to social media to voice their concerns (Aten, 2020). Lack of communication in a crisis, especially a health crisis with lasting health and wellness effects, is contrary to crisis best practices (e.g., Coombs, 2007), and is considered both unethical and bad business by many. What has American Airlines done to combat airlines' lack of preparedness for the coronavirus or to amplify their communication with their passengers?

Because of the change in attitude toward flying, expert guidelines, government limitations, and wariness about traveling in general, many airlines and airports stepped up precautions. Early on in the pandemic, they promised their loyal customers that they are taking every step towards making the flying and traveling experience an enjoyably safe one (TSA, 2020). As of April 2020, Airlines like Southwest and Delta promised to ensure social distancing on their flights by keeping middle seats unoccupied, while United offered every passenger hand sanitizer and Lysol wipes when boarding (Brooks, 2020). Southwest Airlines, the only major carrier that does not assign seats, said it would limit the number of seats for sale on each flight in the name of social distancing (Gilbertson, 2020).

Although every airline required masks between April 2020 and present day, due to global mandates, some are doing the bare minimum to meet global standards. And although, as previously mentioned, American Airlines should stand at the forefront in crisis communication due to age and experience, news and customer reports in popular media criticized the airline giant for not delivering on their promises of special promotions, full refunds for all passengers, or social distancing on flights (Gilbertson, 2020). As for the mask mandate, the airline sent out a 
news release on April 30, 2020, promising that all flight attendants would be required to wear face coverings starting May 1, 2020 and passengers would be required to wear face coverings starting May 11, 2020 and that the airline would be providing sanitation packets to passengers as supplies and operational conditions allow (American Airlines, 2020). Whether and the extent to which that promise was followed remains unclear (Glusac, 2020).

Ultimately, American Airlines was chosen to be studied for this research because of its history with crises and reputation for being one of the top four airlines in the United States (IATA, 2015). During the early months of the pandemic, articles and news stories broke about airlines not taking the virus seriously, and American Airlines was most frequently involved in these headlines (e.g., Chokshi, 2020).

American Airlines is fairly active on Twitter, and the organization frequently releases press releases on their website about the happenings of their business. Some of the claims and promises released by American Airlines have been met with unsatisfied feedback on Twitter, as an informal glance at the account reveals and as this research examines more systematically. Early on in the COVID-19 pandemic, photos of overcrowded flights, passengers not wearing masks, and people standing extremely close together have flooded social media sites. American Airlines responded by sharing videos about how they thoroughly clean each flight and have committed to state-of-the-art air filtration systems, as well as social distancing measures and mandatory masks (e.g., American Airlines, 2020). Such tweets, press releases, and customer response tweets will be examined in this research using the lens of situational crisis communication theory to look at response strategies and the applied model of care considerations to investigate the audience-centered ethical components of messaging along with audiences' emotions. This in-depth look at American Airlines' communication during perhaps the largest 
public health crisis in the U.S. of this generation will provide theoretical and practical implications to inform ethical airline crisis communication.

\section{Chapter 2: Literature Review}

To lay the foundation for inquiry and identify research gaps that this research is positioned to fill, the following sections explain why ethical crisis communication is important by defining critical terms such as public relations, crisis communication, crisis management, crisis coping, Situational Crisis Communication Theory, and the Applied Model of Care Considerations along with landscapes of care.

\section{Crisis}

A crisis has been defined as a major occurrence with a potentially negative outcome affecting the organization, company, or industry, as well as its publics, products, services, or good name (Fearn-Banks, 2017). There are three characteristics that separate crises from other unpleasant occurrences. These include surprise, threat, and short response time (Hermann, 1963). Selbst (1978) defined a crisis as any action or failure to act that interferes with an organization's ongoing functions, the acceptable attainment of its objectives, its viability or survival, or that has a detrimental personal effect as perceived by the majority of its employees, clients, or constituents (as cited in Faulkner, 2001, p. 136). Thus, a crisis is generally thought of as being harmful and detrimental to an organization (cf, Fraustino \& Liu, 2017). Generally, from the perspective of mitigating damage to the organization, in many larger, for-profit organizations, there is a public relations team or crisis communications team that handles relaying useful information output to its publics. 
It should be noted that not all crises are the same, and some could be considered more detrimental than others. To describe a crisis that could potentially be seen as a threat or a challenge for an organization, and not a fatal or life changing crisis that requires everyone to stop what they are doing and devote complete company attention, researchers have offered the idea of “paracrisis.” Coombs and Holladay (2012) define a paracrisis as a publicly visible crisis threat that charges an organization with irresponsible or unethical behavior, or a crisis threat. A paracrisis is primarily a reputational threat. Any information that asserts unethical or irresponsible behavior is a form of negative information about an organization (Coombs \& Holladay, 2012). While this research focuses more on the emotional health and wellbeing of those effected by an organizational crisis than organizational reputation, it is important to understand that crisis communication can pertain to a paracrisis, and that reputational threat can be considered a crisis by an organization. Paracrisis also intertwines ethical communication and crisis communication in a great way, laying the framework for what is to be discussed throughout this thesis. Public relations and crisis communication are discussed in more detail below.

\section{Public Relations}

Public relations can be defined as a strategic communication process that builds mutually beneficial relationships between organizations and their publics (PRSA, 2020). Public relations involves the strategic process of managing communication between an organization and its publics to build relationships and achieve mutual benefits (J. E. Grunig \& Hunt, 1984). Grunig and Hunt (1984) developed four models of public relations that describe the field's various management and organizational practices. The four models are the press agent/publicity model, public information model, two-way asymmetrical model, and two-way symmetrical model. In 
the press agent/publicity model, communications professionals use persuasion to shape the thoughts and opinions of key audiences. The public information model presents more unbiased information than the press agent model. The two-way asymmetrical model uses research to better understand the audience's attitudes and behaviors, which in turn informs the message strategy. Finally, the two-way symmetrical model argues that the public relations practitioner should serve as a liaison between the organization and key publics to incorporate the needs and wants of both, rather than as a one-sided persuader (Grunig \& Hunt, 1984). These four models explain the various roles a public relations professional or department may take on, depending on the organization's needs.

For the purpose of this research, the following sections will focus on the public relations professionals and departments of large, for-profit organizations. The reason for this specification is because, at a small company, one public relations professional may have to handle all the roles themselves, including crisis management, crisis coping, and response strategy, all of which will be explained below. At larger companies or for-profit organizations, staffers can have more specialized roles, or even entire specialized teams or departments, to handle different organizational needs, like crisis communication.

\section{Crisis Communication}

Two other types of communication are often referred to in various scholarly articles and journals in relation to crisis communication. They are risk communication and disaster communication. Risk communication refers to the exchange of real-time information, advice, and opinions between experts and people facing threats to their health, economic, or social wellbeing. The ultimate purpose of risk communication is to enable people at risk to make informed decisions to protect themselves and their loved ones (WHO, 2020). To communicate risk 
effectively, we need to understand who the target audiences are and the challenges they are likely to face (Viswanath, 2012). Disaster communication differs from crisis and risk communication because disasters are normally unpreventable and unpredictable. For example, hurricane communication differs from bad press communication, and tornado communication differs from a personnel crisis within an organization. With these similar terms now briefly addressed, it is important to differentiate and define crisis communication for the purposes of this study.

Crisis communication is often considered in academic scholarship as a subdomain or offshoot of public relations (cf. Avery, Lariscy, Kim, \& Hocke, 2010). Crisis communication, as a form of communication between an organization and its publics in a time of need, has been examined in multiple domains. Public relations and communication scholars have honed in on crisis communication, describing it as the construction and dissemination of public messages in the event of natural disasters, accidents, and other incidents likely to induce fear, anxiety, or unrest. Communication efforts surrounding crises and emergencies were once only examined in terms of post-incident responses (Lachlan, Spence, \& Eith, 2014). Researchers have found that post-crisis communication can be used to repair the reputation and/or prevent reputational damage (Coombs \& Holladay, 2005), but more modern thinking suggests that crisis communication should take into consideration the effect of pre-crisis, during crisis, and postcrisis communication. Crisis communication efforts are a continual process, rather than merely a post-crisis response (Coombs 1999).

How a public relations professional handles a crisis, acting as the voice of the organization (or influencing the voice of the organization) can make or break the organization's reputation. Research shows that positive relationships between a company and its stakeholders, plus a $\mathrm{CEO}$ who plays a visible leadership role during a crisis may allow for a more genuine and 
relatable communication strategy during a crisis (Fearn-Banks, 2016). For example, when a Lufthansa pilot purposely crashed a plane that killed 150 passengers into the French Alps in 2015, CEO Carsten Spohr shared a sincere apology in his first appearance after the crash. Spohr displayed deep emotion and empathy with the victims, their family, and friends, defining the crash as the company's worst nightmare. Beyond the verbal apology, the company's actions demonstrated remorse and care for those most vulnerable: they offered flights to families to get them as near to the scene of the tragedy as possible and created a reception area to help protect them from unwanted media intrusion (Holger \& Sebastian, 2003). Additionally, the company showed signs of following best practices in crisis learning. Within three days of the Lufthansa plane crash, the company instituted a new policy requiring two pilots in the cockpit at all times. This example demonstrates good crisis communication and a thorough crisis communication strategy.

As touched on in the first paragraph of this section, crisis communication is often only thought of as post-crisis communication, used to save an organization's reputation after a crisis takes place. Good crisis communication and crisis communication strategy consider five stages of crisis preparation and execution. These stages include detection, prevention/preparation, containment, recovery, and learning (Coombs, 2007). A large part of the first stage, detection, is knowing about warning signs and prodromes (Fearn-Banks, 2017, p. 5). A prodrome is an event or early symptom that can project or precipitate a much larger problem to come, and to be able to recognize what the different types of prodromes there are in certain situations, is important (Darling, J., Seristö, H., \& Gabrielsson, M, 2005). The topic of prodromes will be considered during the data collection section of this work and used to help make recommendations. 
Although there is ample research on crisis communication, research on United States airline crisis communication is lacking. There are a few studies that provide examples of good airline crisis communication practices, but these studies do not cover the emotional and ethical detriments of airline crisis communication. For example, in 2004, a study was done on the influence of responsiveness, accessibility, and professionalism on journalists' perceptions of Southwest Airlines public relations. The study found that Southwest Airlines' public relations were accessible and effective, with many journalists included in the study giving the airline an excellent review (Callison \& Seltzer, 2010). While this study did provide insight into major United States airline companies' public relations efforts, it is lacking the crisis communication component, particularly from a care-based ethics framework.

Another study explains United Airlines' and American Airlines' online crisis communication following the September 11 terrorist attacks on the United States. This study found that the Web enabled both companies to provide an immediate response to the attacks. The Web also allowed United and American to offer frequent updates about the incidents to their publics and to communicate their crisis response process to various publics simultaneously (Greer \& Moreland, 2003). While this specific instance of airline crisis communication can be looked upon favorably, it only considers the airlines' web communication and is viewed as a success from the organization's standpoint, without taking into consideration the opinions and emotions of the publics affected by this crisis.

Additionally, some studies examine the cross-cultural nature of crisis communications, especially in situations where companies, such as transnational airlines, have a global market (Pinsdorf, 1991), the role of internal communication and training in building corporate brands (Chong, 2007), and there is even a case study of Malaysia Airlines' media relations and crisis 
communication during the MH370 disaster that argues that the unfavorable representation of Malaysia Airlines by its media stakeholders was complicated by both controlled and uncontrolled crisis elements ranging from information void to fragile relationships with the press (Maydell \& Zafra, 2018). While these studies may provide us with the framework and background needed to draw conclusions about airline crisis communications, they do not give us the full story or take into consideration the emotions and wellbeing of airline customers and affected publics during crises, underscoring that airline crisis communication research is lacking and should be further explored, particularly from an audience-oriented and ethics-based standpoint (Fraustino \& Liu, 2017).

\section{Crisis Communication on Social Media}

It should be noted that social media now plays a large role in organizational crisis communication. Technological advances are transforming how crisis management professionals and researchers view, interact with, and disseminate information to affected communities in a crisis situation. Research shows that on-site and online crisis response activities are becoming increasingly 'simultaneous and intertwined' (Palen, Vieweg, Sutton, Liu, \& Hughes, 2007). For example, Twitter was used to quickly share initial information and updates during the 2007 and 2008 California wildfires, 2008 Mumbai massacre, 2009 crash of US Airways Flight 1549, 2010 Haiti earthquake, and 2011 Tunisian uprising (Beaumont, 2008; Lenhart, 2009; New America Media, 2011; Robinson, 2010; Smith, 2010b; Sutton, Palen, \& Shklovski, 2008). There are many different features of each social media site. Public Relations professionals can use the new media tools to encourage preparedness, spread knowledge, and make the topic at hand, the crisis, visual and interactive. Additionally, these tools allow for question to answer reciprocity, meaning that organizations can connect with and interact with their publics like never before. Ultimately, users 
can voice complaints vocally and publicly, and pressure organizations to respond because their complaints are on social media for other users to see. This means that an organization must be in a constant state of consumer relations, making a public relations professional's job even more vast.

\section{Public Relations in Crisis Communication}

Public relations departments in larger organizations are usually the entities that cope with publics' expectations and needs and navigate organizations through crises (Kamil, 2020). The process of navigating an organization and its publics through a crisis is a type of communication called crisis communication (Coombs, 2007), defined and examined above. These specific public relations teams within the large organization can help build relationships with their organizations' publics and prevent backlash before, during, and after a crisis takes place (Kamil, 2020). For example, the Johnson \& Johnson cyanide-laced Tylenol capsules crisis (in 1982) had a crisis communication team (Berge, 1990), Pepsi utilized its crisis communication team when there were rumors of Pepsi can tampering (The Associated Press, 1993), and Cadbury utilized its crisis communication team to help salvage its good name after worms were found in their candy bars (Telang \& Deshpande, 2016).

Public Relations professionals also have to take into consideration their companies' corporate social responsibility (CSR) to their consumers. The World Business Council defines corporate social responsibility as "the commitment of business to contribute to sustainable economic development working with employees, their families, the local community and society at large to improve their quality of life (World Business Council 2005). An examination of corporate social responsibility literature indicates that the rationale and assumptions behind the 
corporate social responsibility discourse are: (1) corporations should think beyond making money and pay attention to social and environmental issues (2) corporations should behave in an ethical manner and demonstrate the highest level of integrity and transparency in all their operations (3) corporations should be involved with the community they operate in terms of enhancing their social welfare and providing community support through philanthropy or other means (Banjeree, 2008). COVID-19 has brought to light the importance of CSR for many people. For example, in light of social distancing mandates caused by the COVID-19 pandemic, corporate social responsibility has been taken to a new level. One of the most widespread manifestations of CSR is the company's ability to transition to remote forms of activities, like working from home, going to school from home, taking work out classes from home, among other things. It would be impossible for an airline to fly people from home, but other forms of airline CSR during a health crisis like COVID-19 could be the blocking of middle seats, required social distancing in lines to board planes, and mandatory handsfree/mobile ticketing, so that customers do not have to touch frequent touchpoints like ticket kiosks. To summarize, corporate social responsibility is a large part of a public relations professional's role, and literature suggests that ethical communication is a large part of corporate social responsibility.

That being said, there are many ways to communicate ethically, with corporate social responsibility in mind. Some different areas of communicative importance for a public relations professional or team might include media relations, community relations, employee and internal relations, and consumer relations (Bernstein, 2011). An organization might use traditional public relations strategies and tactics such as paid, earned, owned, and shared media to communicate with their consumers. Paid media tactics could include native advertising or social media posts used to reach those affected by the crisis. Earned media tactics could include media releases to 
reach their publics with important messages during a crisis through articles written about the airline from outside media or positive reviews on the airline's website and social media channels. Owned media tactics could include social media and email marketing, and shared media tactics could include user-generated content from airline passengers or employees and content distribution on social media sites (Li, Larimo \& Leonidou, 2020). The strategies and tactics the airline chooses to use to communicate with their publics can be based on or understood through crisis communication theory, discussed below.

\section{Crisis Communication Theory}

There are a few theories that help us better understand what "good" crisis communication is and how it benefits (or the lack thereof detracts from) an organization and its publics. A theory in this context is used to explain what will work, what decisions should be made, and how or what actions are likely to result in a good outcome (Fearn-Banks, 2017). The following theories are some of the primary that have been used in crisis communication literature to describe how and why an organization communicated the way it did. Apologia Theory is an effort to defend the reputation and protect the image of a company, but it is not necessarily an apology. With Apologia Theory, the organization may deny, explain, or apologize for the action through communication discourse (Fearn-Banks, 2017). Image Restoration Theory or Image Repair is an approach for use in developing and understanding messages that respond to corporate image crises. The key to understanding image repair strategies is to consider the nature of attacks or complaints that prompt such responses or instigate a corporate crisis. An attack has two components: the accused is held responsible for an action, and that act is considered offensive. This theory provides five broad categories of image repair strategies that assist in responding to threats. These five are denial, evasion of responsibility, corrective action, reducing offensiveness, 
and mortification (Benoit, 1997). Diffusion Theory examines how new procedures, practices, and objectives are adopted and accepted by companies and individuals, based on the variables of the past and decisions made (Fearn-Banks, 2017, p. 20). Perhaps the most widely discussed crisis communication theory, and that most relevant to the current work, is the Situational Crisis Communication Theory.

\section{Situational Crisis Communication Theory}

The theory most relevant to this research is the Situational Crisis Communication Theory. Situational Crisis Communication Theory (SCCT) suggests that before an organization turns to developing messaging to protect their reputation in a crisis, they first and foremost are supposed to give coping information for (1) physical coping and (2) psychological coping (Coombs, 2007). Yet, in studies evoking SCCT, emotional care is rarely mentioned outside the realm of coping, which itself is also rarely examined from within this framework. Ultimately, SCCT provides evidence-based guidance for organizations to protect their reputation and provides reputational repair strategies for post-crisis communication, which is important work for crisis communicators; however, the literature lacks attention to crisis care, both before and after a crisis, for customer and employee emotions and particular vulnerabilities.

More specifically, rooted in Attribution Theory, a theory that claims that humans are motivated to assign causes to their actions and behaviors (Heider, 1958), SCCT shows us that people do attribute responsibility to organizations during a crisis and will react emotionally to these events. A person attributes responsibility for an event and will experience an emotional reaction to the event, but that is as far as SCCT gets into the realm of emotions pertaining especially to the customer or consumer - and a common emotion in this context of study is generally anger and how public anger can negatively influence the organization. Yet, SCCT is 
important to this research because it lays a foundation for emotionally fueled responses and proposes a need for further expansion and exploration of how crises affect customers' emotions and attitudes after a crisis, based on the organization's proactiveness and response strategies. SCCT suggests that crisis managers should match their crisis responses to the level of crisis responsibility and the reputational threat posed by a crisis (Coombs, 2007). So, it is also a useful framework for the current work to organize and understand organizational response strategies.

SCCT can be broken into three crisis clusters; victim cluster, accidental cluster, and intentional cluster (Coombs, 2007). An example of a victim cluster would be a natural disaster and is referred to as the victim cluster because the organization is viewed as the victim. An example of an accidental cluster would be a food product found to carry E. coli at a grocery store and is referred to as the accident cluster because the fact is unintentional by the organization. An example of an intentional cluster would be an organizational misdeed, and it is considered purposeful (Coombs \& Holladay, 2002). As previously mentioned, SCCT provides evidencebased guidance for organizations to protect their reputation and provides reputational repair strategies for post-crisis communication, but the literature lacks attention to crisis care, both before and after a crisis, for customer and employee emotions. Some important parts of SCCT are outlined and defined below.

\section{Crisis Responsibility}

People either blame the organization or the situation. The more responsibility stakeholders attribute to the organization, the more the crisis response team must appear to accept responsibility for the crisis (Coombs \& Holladay, 1996, 2001, 2002). If people blame the organization, people react angrily and negatively toward the organization. If blame is attributed to a situation, however, the general public appears to be more understanding and act with 
empathy (Coombs, 2007). Three negative reactions to attributing crisis responsibility to an organization have been documented: (1) increased damage to an organization's reputation, (2) reduced purchase intentions, and (3) increased likelihood of engaging in negative word-of-mouth (Coombs, 2007b; Coombs \& Holladay, 2006). It should be noted that most crisis responsibility literature mostly takes into consideration how much responsibility the public attributes to the organization for the crisis at hand, not how much responsibility the organization itself takes for the crisis at hand. It is hoped that this research will shed light on the fact that the amount of responsibility an organization takes for the crisis at hand is an important part of caring about the publics affected by the crisis.

\section{Response Strategies}

A crisis response strategy or the type of messaging an organization sends after a crisis, has significant ramifications for its reputation (Barton, 2001; Benoit, 1995; Coombs, 1999). SCCT provides a crisis manager with three basic options, and three basic levels: minimal, low, and strong, for using crisis response strategies: (1) establish that no crisis exists, (2) alter the attributions about the crisis event to make it appear less negative to stakeholders, or (3) alter how stakeholders perceive the organization-work to protect/repair the reputation (Coombs \& Holladay, 1996). The type of response, however, depends on the crisis type, its severity, and the responsibility stakeholders will attribute to the organization (Barbe, 2018).

Understanding how people process emotions in a crisis is a critical part of this research and a company's response strategy, because emotions affect a person's attitude toward an organization, or an event associated with an organization (Coombs, 2015). "By understanding how people take in information during a crisis state, we can better plan to communicate with them" (CDC, 2019). During a crisis, the speed of a response can be an important factor in 
decreasing harm. In the lack of information, the publics may begin to wonder and fill in the blanks (Coombs, 2015). These quick-fire responses, however, could create a new problem. The first message to reach publics is often their accepted message, even though more accurate information may follow. When new, perhaps more complete information becomes available, individuals compare it to the first message heard. So, the first message needs to be relayed quickly, but it also needs to be informative and accurate (Coombs, 2015). Because of the ways that humans process information while under stress, when communicating with someone facing a crisis or disaster, messages should be simple, credible, and consistent in an emergency (CDC, 2019). Experimental studies by Coombs and Holladay (1996) and by Dean (2004) found that organizations did experience less reputational damage when an expression of concern is offered versus a response lacking an expression of concern. As stated, the Malaysia Airline crisis caused minimal detriment to the company, perhaps in part because of its quick and sincere response strategy.

There are various response strategies listed within SCCT. These strategies include the rebuilding strategy, the diminish strategy, the deny strategy, and the bolster strategy. The rebuilding strategy "aims to rebuild relationships with stakeholders by redeeming the organization's reputation. This is achieved by taking responsibility for the crisis and offering apologies or compensation to those affected by the outcome" (Amaresan, n.d.). The diminish strategy is valuable when the company is not responsible for the crisis but needs to respond in some way. The strategy works to minimize the amount of responsibility placed on the organization which is achieved by offering excuses for or justifying the company's actions (Amaresan, n.d.). The deny strategy is what it says, the company will deny having any 
responsibility for the crisis. The bolster strategy uses previous good works to boost the organization's good name (Coombs, 2007).

In addition to crisis type playing a role in attribution of responsibility, and thus reputational threat, there are other variables that factor into intensifying or diminishing attributions. Two such important variables are the history an organization has with similar or different crises and the prior relationships the organization has built with its publics.

\section{Crisis History}

Past crises play an important role in how an organization is expected to handle a crisis. SCCT suggests that information about past crises can shape perceptions of the current crisis, influence the reputational threat presented by the current crisis, and, hence, such considerations should guide the optimal communication responses for protecting the organizational reputation (Coombs \& Holladay, 2002). The existence of one or more crises may indicate that the current crisis is part of a pattern (stable) rather than an isolated incident (unstable)- therefore, a history of past crises could lead to stronger attributions of organizational responsibility (Coombs, 2004). Unfortunately, American Airlines has been dealing with crises since 1943 (American Airlines, 2020), and was part of the largest airline crisis in the United States, the September 11 terrorist attacks. Fortunately, because of the abundance of problems and crashes, the airline has experience with crisis and crisis communication as a whole, or so one would think. As stated in this paragraph, research shows that organizations should learn from past crises and communicate accordingly. This work will show that even though American Airlines has an abundant crisis history, their communication to the publics they serve during the COVID-19 crisis leaves a lot to be desired.

\section{Prior Reputation}


Reputation is important for any organization. In general, reputation is how the general public, stakeholders, and competitive businesses perceive an organization (Coombs, 2007). Prior reputation, or the before reputation, is especially important in a crisis because an organization with a more favorable prior reputation will still have a stronger post-crisis reputation, because it has more reputational capital to spend than an organization with an unfavorable or neutral prior reputation (Coombs, 2007). There are a few intensifiers, or factors, that could help or further damage a reputation. If an organization has a favorable pre-crisis reputation, this can create a halo effect during a crisis. The prior reputation/halo might work as a shield that deflects the potential reputational damage, or the prior reputation/halo might encourage stakeholders to give the organization the benefit of the doubt and reduce attributions of crisis responsibility (Coombs \& Holladay, 2006).

On the contrary, neuroscientist Dr. Rick Hanson discovered that the brain internalizes negative experiences more deeply, so when you have a negative, fear-based, shameful experience or an insecure thought, our mind wraps around it like Velcro (Hanson, 2013). These two types of crisis intensifiers can have a direct effect on an organization's relationship with its customers. After a crisis, consumers are reluctant to change their initial attitude toward an organization and therefore attribute less responsibility for a crisis to organizations with a favorable pre-crisis reputation (Claeys \& Cauberghe, 2014). Therefore, it is important for an organization to keep a good name pre-crisis, and to respond in a short time and with empathy towards their consumers during and after a crisis, to keep their good name intact.

\section{Crisis Management}

Those who manage crisis response and crisis strategy for a crisis communications team partake in crisis management. Crisis management is a process of strategic planning for a crisis or 
negative turning point (Fearns-Banks, 1996). This process removes some of the risk and uncertainty from the negative occurrence and thereby allows the organization to be in greater control of its destiny (Ulmer, et al., 2010, p. 2). Crisis management has evolved from just emergency preparedness into four factors: prevention, preparation, response, and revision (Coombs, 2014, p. 5). Crisis management can be divided into three phases: (1) pre-crisis, (2) crisis response, and (3) post-crisis. The pre-crisis phase is concerned with prevention and preparation. The crisis response phase is when management must respond to a crisis. The postcrisis phase looks for ways for the organization to better prepare for the next crisis and fulfills commitments made during the crisis phase including follow-up information (Coombs, 2007).

As stated previously, most theorists and scholars discuss crisis communication in relation to an organization and the organization's reputation. This thesis proves that there is a need for organizations to expand beyond dollars and reputation when it comes to a crisis and communicate ethically, with their public's emotions and well-being in mind. Many theories, like Situational Crisis Communication Theory, guide crisis management and public relations professionals managing the crisis at hand about how to protect the organization's reputational assets, but to be ethical, crisis managers must begin their efforts by using communication to address the physical and psychological concerns of the victims (Coombs, 2007).

\section{Crisis Coping}

Although publics tend to experience negative emotions during crises, they also cope with stressful situations differently (Duhachek, 2005; Jin et al., 2012; Lazarus, 1991). In recent years, the topic of crisis coping has shifted from the earlier focus of positive and negative states on crisis decision making and crisis responsibility (Coombs \& Holladay, 2005), to the exploration of the importance of examining specific emotions rather than global feelings (Coombs \& 
Holladay, 2005, Garg et al., 2005). Using this perspective, research can dive deeper into the conceptual theories of emotional crisis rather than theories based purely on corporate responsibility and restoring a company's image. Crisis coping is a concept embedded within crisis management. Coping is a less frequently explored aspect of public relations but has a growing need to be investigated because of the impact coping has on publics emotional health and wellbeing. Past researchers have proposed two different types of coping: problem-focused coping and emotion-focused coping (Lazarus \& Folkman, 1984).

In short, problem-focused coping is coping that solves a problem and emotion-focused coping involves feelings. Lazarus and Folkman (1984) suggested that coping effectiveness plays an important role in the impact of perceived stress on psychological outcomes: Effective coping strategies such as problem-focused and emotion-focused result in mitigating stress by managing situations. Carver et al. (1989) further explained that problem-focused coping aims at problemsolving or doing something to alter the perceived stress. Emotion-focused strategies (also symptom-focused or avoidant strategies) concentrate on minimizing the emotional outcomes of the problem (Lazarus \& Folkman, 1984). Mitigating stress is a crucial aspect of the act of coping and caring for their various publics' emotional health and wellbeing. When an organization readily has coping resources available during and after a crisis, the organization can assist in mitigating their customers and consumers stress and anxiety surrounding the crisis.

Crisis coping has become increasingly crucial in recent years, especially in instances such as the global pandemic still shocking the globe at the time of this writing. Larger companies are realizing that they have an emotional and ethical obligation to care for the vulnerable people they have power over. It is human understanding that individuals will eventually have to come to terms with and work through what they have negatively experienced during a crisis, and crisis 
coping, as well as crisis coping planning, is a significant step in crisis communication.

Shepherding human subjects, with real emotions and feelings, through a crisis is more important than the business or organization surviving the crisis. It could be argued that the subject of the currently proposed case study, American Airlines, for example, should have taken into consideration how their pandemic communication would influence their customers' and employees' emotions and their ability to cope. For example, many American Airlines customers could have lost jobs or loved ones to COVID-19 and neglecting to take into consideration their customers emotional wellbeing in communication concerning people's money or ways to get to their loved ones would be ethically concerning. The following section delves into why crisis communication should be considered ethical communication.

\section{Ethics and Emotions in Crisis Communication}

Because crisis communication is related to salvaging relationships in many realms, emotions and ethics are important. Although there is quite a bit of research on crisis communication in relation to what an organization should and should not do, research on ethics in crisis communication is less pervasive. Systematic quantitative reviews of public relations and related journals spanning more than 30 years, from 1975 to 2009, mentioned not a single article centered on ethics in crisis communications (An \& Cheng, 2010; Avery et al., 2010). The ethics focus has expanded slightly since then, but not to the depth and effects of the more reputationalrelated research trajectories. Although examining audience emotions is beyond the scope of this project, it is important to understand how emotions are related to coping and how coping is related to ethics in crisis communication.

Philosophically, ethics involves realizing the concepts of right and wrong behavior (Fieser, n.d.). Ethics in public relations gets a bit more complicated. "Ethics is more than simply 
following the letter of the law. It is fallacy to assume that everything that is legal is also morally correct; it is equally problematic to presume that everything you consider to be ethical must therefore be legal. Law and morality are related, but they are certainly not the same thing" (Parsons, 2016, p. 8). Writing a press release describing the scene of a deadly plane crash may be factually accurate and legally permissible, but is it ethically or morally correct to describe something in such gruesome detail? How the crisis response team views ethics and feels emotion plays a large part in how the company or team responds. Emotions energize the ethical quest. A person must be emotionally interested enough and care enough about discerning the truth to persevere despite distractions. Even more, a person who wrestles with moral questions is usually emotionally committed to doing good and avoiding evil (Callahan, 1988).

Perceptions of ethics are another key factor that should be taken into consideration when an organization communicates. Within the field of public relations and crisis communication, ethics tends to involve the importance of communication itself. In the literature, if a company is perceived as ethical, they communicate based on truth-telling and an understanding of all viewpoints during a crisis, which logically implies transparency (Kim, 2015). One could conclude that if a company is seen as ethical, they tell the truth and are transparent with their publics. If people perceive a company to be unethical, they could be referring to the fact that the organization might try to hide the truth or go back on their word. Perceptions of ethics have the ability to influence company outcomes, and as such ethics and emotions are key components in successful crisis communication.

For clarity, it is imperative to differentiate the word emotion from the word affect. Many scientists use the word affect when really, they mean emotion. As a result, in the science of emotion, the word affect can sometimes mean anything emotional. This is unfortunate because 
affect is not specific to emotion; it is a feature of consciousness (Barrett, 2017). Emotions can be defined as personal experiences or states, like anger, disgust, fear, happiness, sadness, and surprise (Ekman, 1999). This research, as a whole, will investigate the extent to which American Airline's crisis response reflected care-based ethics and a commitment to their passenger's emotional wellbeing during and after the crisis, instead of investigating how the crisis affects the forces that precede, produce, and inform these emotions. Instead of using affect as an umbrella term for feeling or mood, emotion will be used and considered when referring to how a consumer reacts to crisis communication.

In crises, emotions function as "one of the anchors of the publics' interpretation of the unfolding and evolving events" (Jin et al., 2012, p. 268). The Integrated Crisis Mapping model proposes that anger, fright, and anxiety are the primary emotions publics feel during crises. Fright is an emotion felt when facing an uncertain and existential threat (Lazarus, 1991, 1999). Anger is experienced in responses to a demanding offense against "me" and "mine" (Lazarus, 1991), such as certain offenses caused by organizations in crisis. Publics experience anxiety when they face an imminent, specific, and overpowering threat (Lazarus, 1991).

Crisis communication inherently involves vulnerable individuals surrounding something "wrong," so ethics are (or should be) central. Ethical communication entails the acceptance and understanding of three key elements: what one hopes to achieve through the communication, how one chooses to communicate, and the "real-world" outcomes of communication (Makau, 2009). While a lot of research surrounding SCCT is organizationally focused, the points explained above provide insight into what an organization can do to offer emotional compensation to those directly affected by the crisis and show that SCCT is not solely focused on saving the reputation of the organization but has room for expansion into those under- 
researched guidelines of first ensuring that publics are offered sufficient instructing/adjusting information. Caring about those emotionally and mentally affected by a crisis is a topic that should be expanded upon in academic research, as it is in the Integrated Crisis Mapping Model as described above as well as in the emerging Applied Model of Care Considerations as will be discussed in the next section. Analyzing case study data using the AMCC framework will reveal the ethical strengths and weaknesses of American Airlines' communication during a global pandemic. This will present opportunities for applied critiques as well as possible adaptations and/or expansions of the new model.

\section{Applied Model of Care Consideration}

As discussed above, ethical public relations research in regard to customer emotions is lacking. Crisis communication should be considered a form of ethical communication, but there is not a lot of scholarly research surrounding the topic. "One key element of the two-way symmetrical model of public relations is the value it places on resolving the conflict between the organization and its publics," (Grunig, Toth \& Hon, 2000). Communicating to the public during a crisis should be considered the most ethical form of care at that moment. AMCC is a unique model that addresses literature's lack of ethics research.

The AMCC presents cross-cutting care considerations (i.e., relationships, interdependence, vulnerability, reciprocity) and four landscapes of care (i.e., physical, cultural, political/economic, human) (Fraustino \& Kennedy, 2018). Fraustino and Kennedy integrated various feminist normative philosophies to create the Applied Model of Care Considerations. These four landscapes of care will be used in this research to discuss the physical, cultural, political/economic, and human landscapes of American Airlines that have been conveyed via tweets, press releases, and tweet responses. Analyzing case study data using the AMCC 
framework will reveal the ethical strengths and weaknesses of American Airlines' communication during a global pandemic.

\section{Defining Care}

It is widely known that certain traits tend to be associated with men and women, such as assertiveness and submissiveness, respectively (Spence \& Helmreich, 1980). The concept of care has, for a long time, been a women-specific concept. In this traditional Western schema, the woman takes care of the house, the woman takes care of the children, the woman takes care of the husband after his long day's work, the woman takes care of the family by providing for and caring for. Over the years, care has been defined in many different ways. Most care theory is grounded in feminist literature but, over time, the concept of care has been broadened. Theorists have expanded on the gendered definition of care by differentiating between caring about, taking care of, caregiving, and care-receiving (Tronto, 1993). Important to the current work, care is the provision of practical or emotional support (Milligan \& Wiles, 2010). Political philosophers (eg Tronto, 1993; Sevenhuijsen, 2000; Kittay, 1999) have developed a breakdown of care as a political as well as a personal practice and have argued the obligation of care to social justice, among other things. Care can also be considered in more general terms, however, as the proactive interest of one person in the well-being of another (Silk, 2000).

Other researchers have stated that there is a "possibility that care should be conceptualized as an alternative principle of right action," (Veatch, 1998). "Care is now a widely-used concept in welfare state research, firmly established in the literature by feminist analysis," (Daly \& Lewis, 2000). Taking all of these definitions and interpretations of care into consideration, the Applied Model of Care Considerations allows us to view ethics of care from a feminist, ethical standpoint in relation to public relations. Navigating in the landscapes of care 
requires observing and analyzing critically how deeply our personal and societal structures are influenced by ethics, power, and gender (Skærbæk, 2010).

\section{Ethics/Care Considerations}

Ethic of care presumes a humanity-wide desire to be cared for (Noddings, 1984). This claim aligns with that previously stated, where, in the United States, women have traditionally tended to the home and cared for children and family (Gilligan, 1982; Noddings, 1984). Additionally, the central focus of the ethics of care is on the compelling moral salience of attending to and meeting the needs of others for whom we take responsibility (Held, 2006). Concluding that, as an organization, those in charge should care for those they have responsibility for, their customers, employees, and passengers. If we take this vulnerability as the anchor point for an ethic of care, there is no reason that a care ethic could not be applied to the public realm (Vanacker \& Breslin, 2006, p. 204).

The ethic of care's focus on interdependence, mutuality, and reciprocity mirrors our perspective on situational relationship building in public relations (Coombs \& Holladay, 2013). Examining these ideas in the context of an airline's communication during a pandemic can result in practical takeaways for airline communicators, help fill in research gaps in scholarship related to crisis communication ethics in general and for airlines in particular, and provide opportunities for applying and expanding on an applied ethics model as the theoretical framework. From this information, we can gather that the Applied Model of Care Considerations can be used to help guide organizations in living up to their responsibility of caring for their customers' emotional health and wellbeing. The care landscapes on which the model is founded and the particular landscapes of care tailored to strategic crisis communication across the lifecycle that the model provides warrant further investigation next. 


\section{Landscapes of Care}

As the complex social, embodied, and organizational spatialities that emerge from and through relationships of care, landscapes of care open up spaces that enable us to unpack how differing bodies of geographical work might be thought of in relationship to each other (Milligan \& Wiles, 2010). As discussed above, many definitions of care are grounded in feminism and feminist theory. In Foss et al's (1999) view, feminism emphasizes respect for all voicesparticularly those devalued by the dominant culture, or in this case, a dominant organization: American Airlines. This framework allows us to decipher what area might be hurting a relationship between two bodies. "Landscapes of care are thus spatial manifestations of the interplay between the sociostructurally processes and structures that shape experiences and practices of care," (Milligan \& Wiles, 2010). Many would argue that the realms of care only pertain to the health domain or a healthcare setting. It is important to understand that physical landscape, cultural landscape, political/economic, and human landscapes can involve aspects of care. These four landscapes will be discussed in greater detail below.

\section{Physical Landscape}

This landscape of care addresses the material and embodied realities that audiences face (Fraustino \& Kennedy, 2018). The way that each human lives their lives is completely different, so it would be naïve to assume that each person receives and responds to public relations communication and messages the same way. This landscape calls on public relations professionals to consider and care about the lived realities of each person they are trying to reach. Physical landscapes include material resources, geography, and technology (Fraustino \& Kennedy, 2018). Caring about physical landscape would include access to transportation and technology, as well as access to physical buildings and businesses. 
Within the context of airline communication during a health crisis, some physical landscape realities for an airline to consider could be those stranded in an airport because their flight was canceled without warning, or their flight was rescheduled and they were not given proper amenities, and they cannot afford to stay in a hotel. Also, airlines should take into consideration the physical state of the person/customer; in the current global pandemic, for instance, could this customer potentially have COVID-19? Does the airline have preventative measures in place to assist with a health crisis while keeping other passengers safe? Additionally, there could be a language barrier between airline and customer. During the COVID-19 pandemic, for another possible example, many did not realize that international travel would be banned, leaving people stranded in countries that were not their own. All of these are examples of physical landscapes of care that airlines might take into consideration when communicating to its publics.

\section{Cultural Landscape}

This landscape of care addresses the cultural contexts in which audiences and publics are engrained (Fraustino \& Kennedy, 2018). Just as humans in face-to-face conversations politely accept and acknowledge the others cultural understandings and norms, this landscape of care urges public relations professionals to understand their audience and who they are trying to reach within their own realities and norms. To attempt to understand and relate to an audience's culture while recognizing its own cultural parameters lends authenticity to an organization. This type of understanding also leads to more effective, meaningful, and ethical communication between organizations and publics. Some cultural contexts could include race, gender roles, religion, sex, and social norms. 
Culturally, a global pandemic knows no bounds, but the way people are treated based on race, gender, ethnicity, and other socially constructed parameters does. Some cultural realities airlines could have considered in this realm would be that the pandemic could disproportionately impact Latin Americans, African Americans, women, children, and many others. "Women, and particularly women of color, are more likely to work in businesses that are deemed to be 'essential' and in the hardest-hit industries. They are more likely to shoulder the burden of parenting and other caregiving responsibilities. And for women of color particularly, the pandemic is exacerbating longstanding challenges from social determinants of health (SDOH)," (National Women's Health Network, 2020). These are all situations the airline should have considered when communicating with its publics from the perspective of the cultural landscape.

\section{Political/Economic Landscape}

This landscape of care addresses the political systems and economic structures in which audiences and publics are integrated (Fraustino \& Kennedy, 2018). In this landscape, it is important for organizations to consider the political and economic climate of the audience they are trying to reach. Vulnerable publics become even more vulnerable when political and economic factors are added to the mix. Some of these factors could include political censorship, the economic state of the public, taxation, and international policies. Care in this landscape would mean that an organization should consider the wealth disparities, for example, among their publics while crafting public relations messages.

Politically and economically, in March of 2020, at the beginning of the global pandemic, the world, and the United States in particular, was in a frenzy. All of the following were political and economic realities that airlines could have taken into consideration in their communication in this context. For one example, 2020 was an election year for the United States, and one could 
hypothesize that the pandemic was being used as a tool to further polarize the voters of America, fueling the turmoil that later presented itself as attacks on the US Capitol. People were being convinced to choose sides about whether they thought the pandemic was a hoax or whether or they should be begging those around them to wear masks. Additionally, the pandemic caused people lose their jobs, some were not able to pay rent, businesses closed, and schools turned to remote learning, among many other related items that could have a major economic impact in the short and long term.

\section{Human Landscape}

This landscape of care addresses the individual and collective human elements that highlight the need for situational and contextual sensitivities in tailored communications efforts (Fraustino \& Kennedy, 2018). This landscape calls on public relations professionals and organizations to see and treat their audiences as human and acknowledge the power disparities in human relationships. Taking into consideration emotions, health and wellbeing, educational level, families, and networks, as well as individual experiences is, thus, important. In view of these different situations, it is important for an organization to craft messages and communication that are mindful of many human sensitivities.

In light of the global pandemic taking place, for instance, airlines must realize that their customers and potential customers are human, with fears and anxiety about the situation at hand. Being mindful of the various emotions that passengers and customers could have been feeling about travel at the beginning of a global pandemic should have been at the forefront of the organization's communication strategy. 


\section{Research Questions}

The following research questions are offered through incorporating elements from the above review.

RQ1: How, if at all, did American Airlines' crisis communication responses during the first month of the crisis reflect the response strategies defined in Situational Crisis Communication Theory?

The answer to this question is important and relevant to this work because it will assist in bridging the gap between saving an organization's reputation during and after a crisis, and caring about those affected by the crisis, using Situational Crisis Communication Theory as a theoretical grounding. Finding out whether or not American Airlines used response strategies outlined in SCCT in their communication in the first month of COVID-19 will create a starting point for other airlines to reflect on their response strategies, and whether or not they reflect theoretical propositions. This question's findings will lead into RQ2, which will evaluate the level of care American Airlines exhibited in their communication based on AMCC's landscapes of care.

RQ2: How, if at all, did American Airlines' crisis communication during the first month of the COVID-19 pandemic reflect the landscapes of care defined in the Applied Model of Care Considerations?

The answer to this question is valuable because there is a lack of crisis communication research in relation to emotion and ethics, as well as a lack of airline crisis communication research. This research will be a fundamental step in examining how airline communication exhibits ethics or lack thereof, and influences people's emotions and their ability to cope. Based on American Airlines crisis history, one would assume that the airline would know how to ethically 
communicate with their consumers, and this question will assist in proving whether the airlines' communication reflects the landscapes of care in AMCC.

\section{Chapter 3. Methodology}

To learn more about American Airlines' communication during the COVID-19 crisis, I used the qualitative case study method. I analyzed the data collected in this case study using thematic analysis. The qualitative case study approach was chosen for a number of reasons. First, a qualitative study allows the researcher to explore phenomena, such as feelings or thought processes, that are difficult to extract or learn about through conventional research methods (Strauss \& Corbin, 1998). For this study, American Airlines crisis communication was explored to learn more about how crisis response and crisis communication are related to the emotional wellbeing of its customers and publics. Second, qualitative research methods are the best approach when studying phenomena in their natural settings (Denzin \& Lincoln, 2000), and when striving to understand social processes in context (Esterberg, 2002). This study focuses on deep insights about a particular context, focusing on the communication that came from American Airlines during a crisis (i.e., its press releases and social media posts), so it is coming straight from the source instead of highlighting accounts from third-party views (e.g., news generated by outside journalists), along with the social media responses directly from publics communicating with the organization. It should be noted that American Airlines is considered one of the largest airlines in the United States, and even globally. This case study, and case in particular, is important because the data found in this research pertains to a large airline that many smaller, less profitable airlines may look to for guidance. Accordingly, the following sections define qualitative research, case study methodology, and data analysis.

\section{Qualitative Research}


Qualitative research is used to answer questions about experience, meaning, and perspective, most often from the standpoint of the participant. These data are usually not amenable to counting or measuring (Hammarberg, Kirkman \& Lacey, 2016). Three broad categories of qualitative research exist in research: Observational studies, interview studies, and documentary/textual analysis of various written records (Pope \& Mays, 1996). In this work, qualitative textual analysis of American Airlines' documents and social media were performed. Specifically, a qualitative approach is warranted when the nature of the research questions requires exploration (Stake, 1995). Relevant to this proposed study, qualitative research questions often begin with how or what, so that the researcher can gain an in-depth understanding of what is going on relative to the topic (Patton, 2002; Seidman, 1998). The purpose of this study was to investigate the extent to which American Airlines' crisis response reflected care-based ethics and a commitment to their passenger's emotional wellbeing, so a qualitative case study examining the context, organizational communication, and people and their emotions relative to an event seems appropriate.

\section{Case Study Methodology}

A case study is an ideal methodology when a holistic, in-depth investigation is needed (Feagin, Orum, \& Sjoberg, 1991). As stated above, many researchers have defined their own types of case studies. For example, Robert Stake (2000) remarked that case study methodology can be utilized as an attempt to translate experiences from one situation to the next. Stake (2000) also characterized case studies into three main groups: intrinsic, instrumental, and collective. An intrinsic case study is typically undertaken to learn about a unique phenomenon that the researcher can distinguish as different from others. An instrumental case study uses a particular case to gain an expansive appreciation of an issue or phenomenon. A collective case study 
involves studying multiple cases simultaneously or sequentially in an attempt to generate a still broader appreciation of a particular issue. This work is an example of an instrumental case study, because extensive research has been conducted to try to understand the expansive realm of airline crisis communication through a theoretical lens.

According to Yin (2018), case studies can be used to explain, describe, or explore events or phenomena in the everyday contexts in which they occur. Yin (2018) noted that a social science case study should be used when investigating a phenomenon in depth and within its realworld context, as opposed to other variations of case studies (professional/applied case studies) that usually examine a single subject of analysis. For the purpose of this research, I will use Yin's (2018) qualitative social science case study approach guided by crisis communication and feminist ethics literature and using the lenses of Situational Crisis Communication Theory and the Applied Model of Care Considerations.

Case studies from the Yin (2018) social science perspective use a triangulated research strategy. Snow and Anderson (cited in Feagin, Orum, \& Sjoberg, 1991) asserted that triangulation can occur with data, investigators, theories, and even methodologies. To triangulate data to paint a rich picture of this specific case, I propose collecting data from American Airlines' official Twitter account, the airline's press releases, and audience tweets in response to the airline's original tweets. Yin (1994) suggested that the researcher must possess or acquire the following skills: the ability to ask good questions and to interpret the responses, be a good listener, be adaptive and flexible so as to react to various situations, have a firm grasp of issues being studied and be unbiased by preconceived notions. The chosen data collections will allow me to listen and interpret responses to the coronavirus crisis from American Airlines, as well as view and evaluate responses on social media from customers. Yin also suggested that every 
investigation should have a general analytic strategy, so as to guide the decision regarding what will be analyzed and for what reason. He presented some possible analytic techniques: patternmatching, explanation-building, and time-series analysis. The analytic technique used in this research will be explanation-building, with hopes to provide explanations for past airline communication and recommendations, based on the literature discussed above, for current airline crisis communication.

\section{Theoretical Propositions}

For the purpose of this research, I used theoretical propositions to develop explanationbuilding recommendations from the information learned from this study. The theoretical framework used to develop these recommendations for this study, as discussed above, were the Situational Crisis Communication Theory and the Applied Model of Care Considerations. For clarity and as a reminder, the Applied Model of Care Consideration is based on feminist ethics to reflect cross-cutting ethics related to public relations and proposes a set of care considerations across four landscapes relevant to public relations practitioners in all times, spaces, and places: (1) physical, (2) cultural, (3) political/economic, and (4) human (Fraustino \& Kennedy, 2019). SCCT suggests that before an organization begins communicating about a crisis in ways intended to mitigate threats to reputation and reduce reputational damage, they are supposed to give instructing and adjusting information for audience coping and wellbeing (Coombs, 2007). It should be mentioned that SCCT provides evidence guidance for organizations to protect their reputation and provides reputational repair strategies for post-crisis communication, but lacks post-crisis care for customer and employee emotions. These reputational repair strategies are defined above in the Response Strategies section, but as a reminder, Coombs (2007) grouped proposed strategies into three groups which include: denial (attacking the accuser, denial, 
scapegoating), diminishment (excusing, justification), rebuilding (apology, compensation) and bolstering (reminding, ingratiation, victimage). This approach will enable me to examine and criticize crisis communication in the current context in ways that are related to the publics' health and wellbeing.

\section{Data Collection}

In keeping with the triangulated data approach defined above, three artifacts were analyzed: organizational press releases, organizational tweets, and the organizations responses to the publics' responses to the organizational tweets - all within the first month of the crisis.

\section{Press Releases}

The data for this research were collected from American Airlines' press releases on the news tab of their website between February 29, 2020, and March 30, 2020. I analyzed a census sample of the sampling frame: the 28 press releases located on the organization's website released within the timeframe. This timeframe was chosen because in today's world of constant news, a story is old minutes after it is told, and crisis stories often have maximum saliency during the first 30 days of the crisis, as others have researched and applied to their research timeframe justifications (e.g., McCombs \& Chyi, 2004). Timely and constant communication and information from an organization in the midst of a crisis is an important part of a response strategy, as outlined in Coombs (2007) Situational Crisis Communication Theory. The old adage representing key principles of crisis communication, "tell it all, tell it fast," supports the notion that "when information gets out quickly, rumors are stopped" (Seitel 2007, p. 408).

According to Yin (1994), for case study research, interviews are a dominating data source, but alternative data sources exist as well. Alternative data sources can take the form of, for example, letters, memoranda, agendas, announcements, proposals, progress reports, 
evaluations, press releases, and newspaper items (Yin, 1994). Press releases have a broad coverage - a long span of time, with many events - as opposed to interviews that are targeted and focus directly on the research topic (Yin, 1994). Press releases written by American Airlines themselves were chosen as a data source over newspaper or online articles written by journalists covering the company and the pandemic because this research intends to examine the airline's messaging, as noted in the Research Questions section above. Thus, it is prudent to pull data from the organization's communication that best reflects its desired messaging - this is precisely the communication that is contained in press releases that are crafted in advance of release and generally undergo levels of approval before posting. Press releases are an important form of data, especially for this research, because they show us specifically how an organization wants its news to be conveyed and framed. It should be noted that some of press releases included videos, and although the videos were not analyzed, the text from the videos were included in the press release, so that verbiage was analyzed.

\section{Organizational Tweets}

Twitter is a form of microblogging with brief 280 character "tweets" that may consist of images, text, and links (O’Connor, Jackson, Goldsmith, \& Skirton, 2014). Registered users follow other accounts to quickly exchange information and see updates; unregistered users may only read tweets (Stump et al., 2012). Established in 2006, Twitter reports 1.3 billion registered users, 313 million active registered users, and 500 million daily tweets (Finfgeld-Connett, 2015). Twitter is used by $23 \%$ of online adults, with $37 \%$ of users between 19 and 29 years old and $25 \%$ between the ages of 30 and 49 years (Finfgeld-Connett, 2015). In particular, Twitter is ideal for qualitative research because it is one of the most well-established platforms used to discuss a variety of topics (Salzmann-Erikson, 2017). The official Twitter account of American Airlines 
goes by the username @AmericanAir. This account follows 105,600 Twitter users and is followed by 1.6 million Twitter users.

Thus, another form of data for this research was collected by examining and analyzing the organization's tweets on their official Twitter account (@AmericanAir) between March 1, 2020, and March 30, 2020. This one-month period was chosen because timely and constant communication and information from an organization in the midst of a crisis is an important part of a response strategy, often via social media, as outlined in Coombs (2007) and the Situational Crisis Communication Theory, along with the aforementioned reasons.

The data collected from these organizational tweets allows for analysis of how the organization conveyed its messages to a large number of customers and potential customers through a more immediate and humanized media, social media, thereby enabling me to derive answers to my research questions. Twitter was chosen as a platform for data collection because of its unprecedentedly vast scope. During a crisis, when time and space can limit other means of communication, social media can shape and organize crisis communication. Additionally, Twitter communication is not as formal as that of a press release, so it will give a more rounded view of the organization's crisis response. Twitter is often used by companies to increase brand awareness, generate leads and revenues, foster relationships, and create brand loyalty (Kumar \& Mirchandani, 2012, Rapp et al., 2013). Examining these tweets allowed for an analysis of unvetted communication between an organization and its publics.

\section{Responses to Public Tweets}

Lastly, to complete the triangulation of my data, I also included American Airlines' responses to the publics' tweets to their account. That is, these tweets were in reply to user responses to this organization's tweets pertaining to the COVID-19 pandemic on their official 
Twitter account (@AmericanAir) between March 1, 2020, and March 30,2020. While examining the tweets American Airlines sent out to the public, I will also examine their responses to those consumers replying to their original tweet. In analyzing the organizations responses, I will click on the hyperlink in my data set, bringing me back to the original organizational tweet, and I will examine the organizations response tweets and assess what is going on in the specific situation to get a feel for what prompted the organization to respond and how it was perceived by the public by the surrounding responses to the organization's response. The following table shows the organization's tweet, the number of public replies, and the number of times American Airlines responded back to those public replies.

Table 1 Public Response Tweets/AA Response Tweets

$\begin{array}{lcc}\text { Organizational Tweet ID } & \text { Public Response Tweets } \boldsymbol{n}= & \begin{array}{c}\text { Organizational Response } \\ \text { Tweets } \boldsymbol{n}=\end{array} \\ \text { Tweet \#1 } & 12 & 1 \\ \text { Tweet \#2 } & 37 & 3 \\ \text { Tweet \#3 } & 69 & 7 \\ \text { Tweet \#4 } & 57 & 6 \\ \text { Tweet \#5 } & 38 & 4 \\ \text { Tweet \#6 } & 14 & 1 \\ \text { Tweet \#7 } & 424 & 42 \\ \text { Tweet \#8 } & 41 & 4 \\ \text { Tweet \#9 } & 29 & 3 \\ \text { Tweet \#10 } & 495 & 49 \\ \text { Tweet \#11 } & 163 & 16 \\ \text { Tweet \#12 } & 17 & 2 \\ \text { Tweet \#13 } & 12 & 1 \\ \text { Tweet \#14 } & 161 & 16 \\ \text { Tweet \#15 } & 495 & 50 \\ \text { Tweet \#16 } & 99 & 10 \\ \text { Tweet \#17 } & 171 & 17 \\ \text { Tweet \#18 } & 51 & 5 \\ \text { Tweet \#19 } & 130 & 13 \\ \text { Tweet \#20 } & 60 & 6\end{array}$




$\begin{array}{lcc}\text { Tweet \#21 } & 115 & 12 \\ \text { Tweet \#22 } & 111 & 11 \\ \text { Tweet \#23 } & 141 & 14 \\ \text { Tweet } \# 24 & 292 & 29 \\ \text { Tweet } \# 25 & 47 & 5 \\ \text { Tweet } \# 26 & 26 & 3 \\ \text { Tweet } \# 27 & 40 & 4 \\ \text { Tweet } \# 28 & 35 & 4 \\ \text { Tweet } \# 29 & 19 & 2 \\ \text { Tweet } \# 30 & 226 & 23\end{array}$

\section{Data Analysis}

For the purpose of this research, I used a deductive analysis approach. Deductive qualitative research is differentiated from other qualitative approaches in that it takes the theoretical propositions that are derived from a review of the literature as its departure point and applies these to the collection and analysis of data (Boyatzis 1998; Fereday \& Muir-Cochrane 2006; Hyde 2000). The appeal of deductive qualitative analysis is evident in its recommended use in case studies by Robert Yin (Yin, 2014), a preeminent scholar and textbook writer related to the social science case study method. More specifically, to analyze data, thematic analysis was employed. Thematic analysis is a method for identifying, analyzing, organizing, describing, and reporting themes found within a data set (Braun \& Clarke, 2006). As stated above, the deductive version of thematic analysis, or theoretically driven coding, uses theory as its point of departure (Boyatzis 1998).

The benefits of conducting a thematic analysis are that it "can highlight similarities and differences across the data set" and also "usefully summarize key features of a large body of data, and/or offer a 'thick description' of the data set” (Braun \& Clarke, 2006). Following the Braun and Clarke (2006) guide for conducting a thematic analysis, I familiarized myself with the 
data, generated initial codes, searched for themes, reviewed the themes, defined and named the themes, and finally, produced the final analysis. Prior to coding, I compiled key theoretical concepts, variables, and definitions to guide my analysis, and this reference document can be found in Appendix A. The organization's tweets and press releases enabled me to code for and examine which response strategies from SCCT were used, if any, as well as which landscapes of care appeared to have been considered. The major themes that arise, in comparison to my theoretical propositions, will be used to ultimately critique the extent to which American Airlines communicated with their publics in an ethical manner, with customer health and wellbeing reflected, and assist in developing theoretical contributions by applying/testing theories, as well as produce practical recommendations for communication that is entrenched in ethics and audience oriented.

To systematically reduce the data set, the first stage of analysis included coding by hand. The method allowed me to feel the data, and spatially arranging the items, written on index cards, in various combinations permitted me to generate patterns in the data. After patterns were conceived, themes emerged and were supported by the data. Some of my original codes were merged together because they were conceptually similar, and others were assessed for their utility in the overall scheme of this study (Saldana, 2021). A visual, spatially arranged diagram allowed for understanding how the codes, patterns, and themes of this data set worked together. This layout has been adapted into an operational model diagram for this study and can be found in the results section.

For clarity, a code or coding is how a researcher defines what the data they are analyzing is about (Gibbs, 2007). A pattern is generated when similar issues and ideas expressed by participants within qualitative data are brought together by the researcher into a single category 
(Luborsky, 1994). Themes are abstract (and often fuzzy) constructs that link not only expressions found in texts but also expressions found in images, sounds, and objects. "You know you have found a theme when you can answer the question, what is this expression an example of?" (Ryan \& Bernard, 2003).

\section{Personal Bias Reflection}

As stated in the body of this work, it is acknowledged that the use of this qualitative method of thematic analysis is a highly interpretive measure, and thus the researcher needs to reflect on and acknowledge their biases due to their values and emotions concerning the source material. Included in this personal reflection are my thoughts and feelings in approaching and completing this analysis.

It is now widely reported that COVID-19 has impacted many people in a variety of ways. I am fortunate enough to not have had anyone close to me pass away or become gravely ill with the virus. I am also fortunate enough to have been able to continue to go to school and work, without the stress of financial ruin. Additionally, I am privileged because I am a white female who comes from a fairly well-off middle-class family. My parents and siblings have stayed healthy and have continued to attend school and work. My grandparents were all vaccinated during the first few weeks of vaccination availability, and they can stay home and protect avoid exposure to the virus. I live in the United States, so vaccines and free COVID-19 testing has been made available to me free of charge, and have been administered in a timely, orderly fashion.

With all of that privilege explained, my stance on international travel and the way it has impacted myself and my family is more than just not being able to go on vacation or travel the world for pleasure. My mother's family lives in England, and we have not been able to see them 
for over a year and a half. To my family and I, traveling by plane is more than just getting from point A to point B. It is the only way to cross the ocean and visit with our family. My family, and families like ours, have been impacted by this global crisis in more ways than missed vacations. For many of us, it has caused a separation of families and missed opportunities to spend time with loved ones.

This research is personal to me because my family is spread out across the world. When an airplane is the only efficient mode of transportation across an ocean, and the only way to be able to visit your mother or grandmother, a hard stop on international travel becomes detrimental to not only the family dynamic of those affected but also the mental health of all family members involved. This research is important to me because it greatly affects me and the people I am close to, as well as millions of people around the world. I chose to research American Airlines' crisis communication, in particular, because of their crisis history. Because the company has a history of crisis, whether it be terrorist attacks or natural disasters, one would assume that they would be able to ethically communicate to their passengers, to keep their customers emotionally healthy, but their COVID-19 communication efforts have proved otherwise and are explained and analyzed throughout my research.

\section{Chapter 4: Results}

To reiterate, thematic analysis was selected as the tool for this work because thematic analysis emphasizes an organic approach to coding and theme development and the active role of the research in these processes. In addition, positive psychologists are embracing the greater flexibility that they offer to the qualitative researcher (e.g., Holmquist \& Frisén, 2012). The hallmark of this form of TA is its flexibility - not simply theoretical flexibility, but flexibility in terms of the research question, sampling size and constitution, data collection method, and 
approaches to meaning generation (Braun \& Clarke, 2015). TA can be used to analyze large and small datasets - from case study research with 1-2 participants (e.g., Cedervall \& Åberg, 2010) to large interview studies with 60 or more participants (e.g., Mooney-Somers, Perz \& Ussher, 2008). TA can be used for both inductive (data-driven) and deductive (theory-driven) analyses, and to capture both manifest (explicit) and latent (underlying) meaning. Using a deductive thematic analysis approach, the following themes emerged from the data sources used in this work.

My first research question asked: How, if at all, did American Airlines' crisis communication response strategies during the first month of the COVID-19 pandemic reflect the response strategies defined in Situational Crisis Communication Theory?

\section{Crisis Response during the First Month of the Pandemic}

To overview, the data analysis disclosed that American Airlines' crisis communication response strategies during the first month of the COVID-19 pandemic did reflect some of the response strategies defined in SCCT. One of the first key findings was American Airlines' lack of fully publicly accepting the (para)crisis created within their organization by COVID-19. On several occasions, the company appeared to endeavor to divert attention away from COVID-19 and its repercussions, and shift responsibility to a decrease in customer travel, and a decrease in interest in travel. This lack of recognition that repercussions could be attributed to the COVID19 crisis emerged from the data based on a combined result of the coding of "scapegoat" strategy tweets and press releases, excuses, justifications, and the avoidance of the words pandemic, COVID-19, or any apologies within the press releases and data. 
Furthermore, a second key finding was the company's dependency on new community initiatives that exemplify the company's values and mission statement, but, simultaneously, potentially alienate existing support by redirecting community aid to problems unrelated to COVID-19. Was this immediately transparent to the existing customer base as a way for the company to push their current issues aside and bolster a new client market? This finding emerged from the use of communicating external good deeds from the company and bolstering from the company to share good news via press releases and tweets, as well as the advertisement of the other, non-COVID related projects American Airlines was participating in during the first month of the COVID-19 pandemic. While some good deeds were centered around COVID-19 efforts, the mere mention of the virus was rarely used. During analysis of these specific findings, one theme and two related patterns emerged, as described in more depth next.

\section{Theme 1: SCCT Response Strategies}

\section{Pattern 1: Scapegoating}

This pattern encapsulates the unwillingness of American Airlines to fully accept the crisis created within their organization, by COVID-19. For example, in their second press release issued on March 25, 2020, American Airlines said, "American continues to take care of customers during this uncertain time as government-imposed travel restrictions continue to develop." In another press release issued on March 27, American Airlines says, "American Airlines Group Inc. (NASDAQ: AAL) will make further capacity cuts in April and May to address record low customer demand." On March 3, American Airlines tweeted, "Due to reduction in demand, we've suspended operations between Seoul, South Korea (ICN) and Dallas-Fort Worth (DFW)." In all of these examples, American Airlines fails to acknowledge 
COVID-19 and blames changes of schedule and reduction of demand on other, less critical, situations. (All emphases added.)

\begin{tabular}{|c|c|c|c|c|}
\hline Theme & Pattern & Code & Description & Examples \\
\hline $\begin{array}{l}\text { SCCT Response } \\
\text { Strategies }\end{array}$ & Scapegoating & $\begin{array}{l}\text { Not mentioning } \\
\text { the pandemic, } \\
\text { blaming } \\
\text { reduction in } \\
\text { travel on } \\
\text { customers, } \\
\text { blaming capacity } \\
\text { cuts on record } \\
\text { low customer } \\
\text { demand, } \\
\text { schedule } \\
\text { changes due to } \\
\text { customer } \\
\text { demand }\end{array}$ & $\begin{array}{l}\text { To blame } \\
\text { someone or } \\
\text { something else, } \\
\text { prove no crisis } \\
\text { exists, claim no } \\
\text { responsibility }\end{array}$ & $\begin{array}{l}\text { March } 27 \text { PR: } \\
\text { American } \\
\text { Airlines Group } \\
\text { Inc. (NASDAQ: } \\
\text { AAL) will make } \\
\text { further capacity } \\
\text { cuts in April and } \\
\text { May to address } \\
\text { record low } \\
\text { customer } \\
\text { demand. }\end{array}$ \\
\hline
\end{tabular}

\section{Pattern 2: Bolstering Good Deeds}

This pattern encapsulates the company's dependency on underscoring its good work or showcasing new community initiatives that exemplify the company's values and mission statement, but some of which simultaneously may alienate existing customer support by redirecting community aid to problems primarily outside of the immediate COVID-19 needs.

For example, in a press release on March 29, 2020, American Airlines said,

American Airlines is partnering with long-standing national partner American Red Cross to raise funds for the nonprofit's efforts on the frontlines of the coronavirus (COVID19) outbreak. American is proud to be a $\$ 1$ million member of the American Red Cross Annual Disaster Giving Program” (emphasis added). American Airlines tweeted on March 4 that 
Nashville needs your help. Make a @RedCross donation to help tornado victims now through March 17, and you'll receive 10 miles for every dollar spent. Donations must be a minimum of $\$ 25$.

And as they tweeted again on March 6,

Appreciating our \#AATeam all day, every day. Our team members were recognized by customers, their peers, and leaders more than 2.5 million times — that's once every 12 seconds — throughout 2019 and awarded more than \$10.5 million. \#EmployeeAppreciationDay.

\begin{tabular}{|l|l|l|l|l|}
\hline Theme & Pattern & Code & Definition & Example \\
\hline $\begin{array}{l}\text { SCCT } \\
\text { Response } \\
\text { Strategies }\end{array}$ & Bolstering & $\begin{array}{l}\text { ingratiation, } \\
\text { victimage, } \\
\text { good deeds, } \\
\text { bragging }\end{array}$ & $\begin{array}{l}\text { Reminder: } \\
\text { crisis } \\
\text { managers tell } \\
\text { stakeholders } \\
\text { about the past } \\
\text { good works of } \\
\text { the } \\
\text { organization. }\end{array}$ & $\begin{array}{l}\text { March 6 Tweet- } \\
\text { Appreciating our \#AATeam } \\
\text { all day, every day. Our team } \\
\text { members were recognized } \\
\text { by customers, their peers } \\
\text { and leaders more than 2.5 } \\
\text { million times - that's once } \\
\text { every 12 seconds - } \\
\text { throughout 2019 and } \\
\text { awarded more than \$10.5 } \\
\text { million. } \\
\text { \#EmployeeAppreciationDay }\end{array}$ \\
& & & & \\
& & & & \\
\hline
\end{tabular}

\section{Pattern 3: Diminish}

This pattern encapsulates the company's decision to underscore the severity of the pandemic taking place. One way this was evident was through the company by referring to the pandemic as a "situation" in more than one form of communication. By not referencing the global pandemic by its name, American Airlines did not provide clarity to its passengers or employees, and could be diminishing, or lessening the severity of the pandemic. This lack of clarity could lead to confusion and did not allow the organization to be looked upon favorably. 
For example, in a press release March 14, American Airlines said, American will continue to take care of customers as this situation develops.

\begin{tabular}{|l|l|l|l|l|}
\hline Theme & Pattern & Code & Definition & Example \\
\hline $\begin{array}{l}\text { SCCT Response } \\
\text { Strategies }\end{array}$ & Diminish & $\begin{array}{l}\text { avoidance, } \\
\text { excuse, } \\
\text { provocation, } \\
\text { defeasibility, } \\
\text { accidents, good } \\
\text { intentions, } \\
\text { justification }\end{array}$ & $\begin{array}{l}\text { Diminish crisis } \\
\text { response } \\
\text { strategies should } \\
\text { be used for } \\
\text { crises with } \\
\text { minimal } \\
\text { attributions of } \\
\text { crisis } \\
\text { responsibility } \\
\text { (victim crises) } \\
\text { coupled with a } \\
\text { history of similar } \\
\text { crises and/or } \\
\text { negative prior } \\
\text { relationship } \\
\text { reputation. }\end{array}$ & $\begin{array}{l}\text { American will } \\
\text { continue to take } \\
\text { care of } \\
\text { customers as this } \\
\text { situation } \\
\text { develops. }\end{array}$ \\
& & & \\
& & & \\
\end{tabular}

These patterns conclude my first theme, SCCT Response Strategies. In the next paragraphs, RQ2 and AMCC themes/patterns will be discussed.

My second research question asked: How, if at all, did American Airlines' crisis communication during the first month of the COVID-19 pandemic reflect the landscapes of care defined in the Applied Model of Care Considerations?

\section{Landscapes of Care}

In overview, data analysis revealed that American Airlines' crisis communication during the first month of the COVID-19 pandemic did not reflect the landscapes of care defined in the 
Applied Model of Care Considerations. American Airlines' lacked messaging reflecting that they acknowledged the severity of the public health crisis and notified their customers about the beginnings of the COVID-19 pandemic promptly. On January 31, 2020, the World Health Organization declared a Global Health Emergency. On February 3, 2020, the United States declared a public health emergency. American Airlines' first tweet regarding and acknowledging a change in flight schedule, or a decrease in travel demand due to COVID-19 specifically, did not come until March 10, 2020. The first press release with information regarding the COVID-19 pandemic did not come until March 5, 2020, where the releases specifically mentioned COVID19. That is a matter of not hours or even days, but weeks or months.

Additionally, American Airlines' press releases, original tweets, and audience response tweets reflected insensitivity with regard to fully making space for and accommodating losses and hardships faced by their past and current clientele. A combination of the airline imposing time constraints to remake travel plans, and the absence of an offer of a full refund for those who might have chosen to cancel travel plans due to the pandemic are examples of business and related communication choices that could be deemed as insensitive to those viewing their tweets and press releases. Also reflecting this theme, there were an abundance of "waiving of change fee" tweets and press releases American Airlines released during the first month of the global pandemic. These "waiving of change fee" press releases made up eight of the 30 press releases issued by the organization, as well as nine of the 31 organizational tweets tweeted by the organization during March 2020. The tweets and press releases used the same talking points.

Additionally, 4 of the press releases include quotes from those at the head of the company. In one of the releases, the president of the company shares that American is dedicated to caring for its customers through this difficult time but does not share any strategies or tactics 
for doing so. Additionally, in the March 26 press release, CEO Doug Parker discusses how the Coronavirus Aid, Relief, and Economic Security (CARES) Act is expected to shape the company's response to COVID-19-essentially asking for sympathy for the company, describing how people staying home is making their team start to worry, and thanking the Senate for passing the CARES Act.

Another key finding in this analysis was American Airlines’ lack of financial consideration for their passengers, who were immediately faced with financial distress, often in

foreign countries and thousands of miles away from home. It should be noted that out of 30 press releases issued by American Airlines in March 2020, this was one of two releases that had the section "Taking Care of Customers," and one of three releases that mentioned the word refund. Other releases that contained the word refund were the March 3 press release, the March 12 press release, and the March 14 press release.

\section{Theme 2: Care}

\section{Pattern 1: Delayed Acknowledgment}

This pattern encapsulates American Airlines' lack of acknowledgement of the public health crisis and lack of prompt notification of their customers about the beginnings of the COVID-19 pandemic. For example, in a March 5 press release, American Airlines said, American Airlines announced today it will waive change fees up to 14 days before travel for customers who purchase travel between March 1 and March 16. This change offers customers the best fares with even more flexibility. The offer is available for any of American's published fares. Additional updates on existing travel alerts can be found on aa.com/travelalerts.

Additionally, in a March 3 press release, American Airlines said, 
Due to the reduction in demand, American Airlines is suspending operations to and from Seoul, South Korea (ICN), and Dallas-Fort Worth (DFW), effective March 4, 2020.

Flights to Seoul are scheduled to resume on April 25. Our teams are contacting affected customers directly to accommodate their needs.

\begin{tabular}{|l|l|l|l|l|}
\hline Theme & Pattern & Code & Definition & Example \\
\hline AMCC & $\begin{array}{l}\text { Delayed } \\
\text { Acknowledgment }\end{array}$ & $\begin{array}{l}\text { no mention of } \\
\text { pandemic, the } \\
\text { "situation", } \\
\text { notification, } \\
\text { informing, } \\
\text { preparedness, } \\
\text { waiving change } \\
\text { fees, "reduction } \\
\text { in demand" }\end{array}$ & $\begin{array}{l}\text { This pattern } \\
\text { encapsulates } \\
\text { American } \\
\text { Airlines' lack of } \\
\text { acknowledgement } \\
\text { of the public } \\
\text { health crisis and } \\
\text { lack of prompt } \\
\text { notification of } \\
\text { their customers } \\
\text { about the } \\
\text { beginnings of the } \\
\text { COVID-19 } \\
\text { pandemic }\end{array}$ & $\begin{array}{l}\text { March 5 PR- } \\
\text { American has } \\
\text { extended its } \\
\text { offer to waive } \\
\text { change fees for } \\
\text { customers who } \\
\text { purchase travel } \\
\text { through March } \\
\text { 31. Customers } \\
\text { will have even } \\
\text { more flexibility } \\
\text { since any ticket } \\
\text { purchased by } \\
\text { March 31 will } \\
\text { not incur change } \\
\text { fees prior to } \\
\text { travel. }\end{array}$ \\
& & & \\
\end{tabular}

\section{Pattern 2: Insensitive Incentives}

This pattern revealed American Airlines' insensitivity to accommodate financial losses and hardships faced by their past and current clientele. For example, in a March 20 press release, American Airlines said

American has extended its offer to waive change fees for customers who purchased tickets prior to March 1 for travel through May 31. The offer is available for any of American's fares and customers have until December 31 to rebook travel for future 
flights. Additional updates on existing travel alerts, including international travel waivers that are available for travel through May 31, can be found on aa.com/travelalerts.

In a March 25 press release, American Airlines said, “American has extended its offer to waive change fees for customers who purchase travel through April 15. Customers will have even more flexibility since any ticket purchased by April 15 will not incur change fees prior to travel. The offer is available for any of American's published non-refundable fares. Additional updates on existing travel alerts can be found on aa.com/travelalerts." The coinciding tweets to these press releases, tweeted on the same days, said, "We're waiving change fees for customers who have travel plans through May 31" and "We're waiving change fees for customers who have travel plans through April 15.”

\begin{tabular}{|l|l|l|l|l|}
\hline Theme & Pattern & Code & Definition & Example \\
\hline AMCC & $\begin{array}{l}\text { Insensitive } \\
\text { Incentives }\end{array}$ & $\begin{array}{l}\text { Change fees, } \\
\text { repetitiveness, } \\
\text { no refund }\end{array}$ & $\begin{array}{l}\text { This pattern } \\
\text { revealed } \\
\text { American } \\
\text { Airlines' } \\
\text { insensitivity to } \\
\text { accommodate } \\
\text { financial losses } \\
\text { and hardships } \\
\text { faced by their } \\
\text { past and current } \\
\text { clientele. }\end{array}$ & $\begin{array}{l}\text { March 1 PR- } \\
\text { American Airlines } \\
\text { announced today it } \\
\text { will waive change } \\
\text { fees up to 14 days } \\
\text { prior to travel for } \\
\text { customers who } \\
\text { purchase travel } \\
\text { between March 1 } \\
\text { and March 16. } \\
\text { This change offers } \\
\text { customers the best } \\
\text { fares with even } \\
\text { more flexibility. } \\
\text { The offer is } \\
\text { available for any of } \\
\text { American's } \\
\text { published fares. } \\
\text { Additional updates } \\
\text { on existing travel } \\
\text { alerts can be found }\end{array}$ \\
\end{tabular}




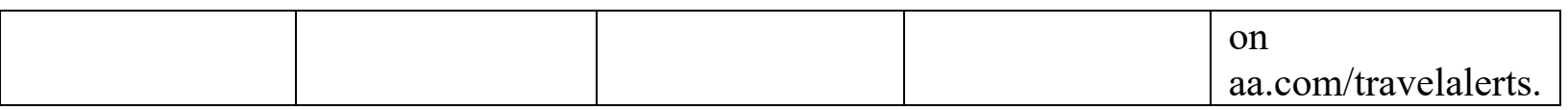

\section{Pattern 3: Capital Over Care}

This pattern in the data reflected American Airlines' lack of financial consideration toward their passengers, who were immediately faced with financial burdens, often in foreign countries and thousands of miles away from home. In one example, in a March 14 press release, American Airlines added a section titled "TAKING CARE OF CUSTOMERS" in which the following appeared:

American will continue to take care of customers as this situation develops. The airline has announced its offer to waive change fees for customers who purchased tickets prior to March 15 for travel to Europe, including the United Kingdom or Ireland, through May 31. Additionally, American's Reservations team will contact customers whose flights have been canceled directly by email or telephone. Customers who booked through a travel agent will be contacted by their agency directly. If a flight is canceled and a customer chooses not to be rebooked, they may request a full refund by visiting aa.com/refunds.

The absence of empathy, no mention of accommodations for those with ticket money tied up with the airline at a time when they may also be stuck away from home with limited or no access to supplementary funds, the multiple processes for attempting to regain unused ticket money, and the perfunctory tone particularly in a section purporting that it is "taking care of customers" contribute to ethically problematic communication unearthed through data analysis relative to this pattern in the theme of care. 


\begin{tabular}{|c|c|c|c|c|}
\hline Theme & Pattern & Code & Definition & Example \\
\hline AMCC & $\begin{array}{l}\text { Capital Over } \\
\text { Care }\end{array}$ & $\begin{array}{l}\text { appreciating } \\
\text { team members, } \\
\text { no refund, } \\
\text { asking for } \\
\text { money }\end{array}$ & $\begin{array}{l}\text { This pattern in } \\
\text { the data reflected } \\
\text { American } \\
\text { Airlines' lack of } \\
\text { financial } \\
\text { consideration } \\
\text { toward their } \\
\text { passengers, who } \\
\text { were } \\
\text { immediately } \\
\text { faced with } \\
\text { financial } \\
\text { burdens, often in } \\
\text { foreign countries } \\
\text { and thousands of } \\
\text { miles away from } \\
\text { home. }\end{array}$ & $\begin{array}{l}\text { March } 26 \text { PR- In } \\
\text { a video shared } \\
\text { with team } \\
\text { members, } \\
\text { American } \\
\text { Airlines CEO } \\
\text { Doug Parker } \\
\text { discusses how } \\
\text { the Coronavirus } \\
\text { Aid, Relief, and } \\
\text { Economic } \\
\text { Security } \\
\text { (CARES) Act is } \\
\text { expected to } \\
\text { shape the } \\
\text { company's } \\
\text { response to } \\
\text { COVID-19. }\end{array}$ \\
\hline
\end{tabular}

\section{Theme 3: Misdirected Focus}

One theme arose in this data analysis that could be considered both a lack of AMCC and SCCT or an entirely new type of response. This theme encapsulates the organization's apparent reluctance to focus on the main problem at hand during March 2020, which was the global COVID-19 pandemic. Each of the data sources showcased the lack of focus on the essential problem, and instead focus on smaller details and issues that might have been handled or promoted at a different time. According to the data, of the 31 tweets tweeted by the organization in March 2020, only 6 mentioned COVID-19 directly, reflecting mentions in only $20 \%$ of the organization's communication during the first month of the life-altering global pandemic. Of the 30 press releases issued by American airlines, only 9 mentioned the word COVID-19. The frequency of tweets and press releases unrelated to COVID-19, with no recognition of the pandemic. 
Some indications of this theme in the data are in a March 6 press release. In this release, American Airlines said,

American Airlines Group Inc. (NASDAQ: AAL) Chairman and CEO Doug Parker will present via webcast at the 2020 J.P. Morgan Industrials Conference on Tuesday, March 10, at 9:30 a.m. ET.”

In a March 2 tweet, American Airlines tweeted, Today's the day. We've been on a journey for more than three years to deliver a new uniform collection for thousands of \#AATeam members. Our new threads have landed, and never looked so good. \#AANewBlue.

In another tweet, American Airlines tweeted, Our \#AATeam volunteers in Tennessee, alongside@feedingamerica and (a) 2 harvestMidTN packed 75,000 pounds of food for families affected by recent tornadoes in the Nashville area." 


\begin{tabular}{|c|c|c|c|c|}
\hline Theme & Pattern & Code & Definition & Example \\
\hline $\begin{array}{l}\text { Misdirected } \\
\text { Focus }\end{array}$ & Focus & $\begin{array}{l}\text { posting } \\
\text { unrelated } \\
\text { messages, } \\
\text { sharing new } \\
\text { uniforms, }\end{array}$ & $\begin{array}{l}\text { This theme } \\
\text { encapsulates } \\
\text { the } \\
\text { organization's } \\
\text { apparent } \\
\text { reluctance to } \\
\text { focus on the } \\
\text { main problem } \\
\text { at hand during } \\
\text { March 2020, } \\
\text { which was the } \\
\text { global COVID- } \\
19 \text { pandemic. }\end{array}$ & $\begin{array}{l}\text { March } 2 \\
\text { Tweet- } \\
\text { Today's the } \\
\text { day. We've } \\
\text { been on a } \\
\text { journey for } \\
\text { more than three } \\
\text { years to deliver } \\
\text { a new uniform } \\
\text { collection for } \\
\text { thousands of } \\
\text { \#AATeam } \\
\text { members. Our } \\
\text { new threads } \\
\text { have landed, } \\
\text { and never } \\
\text { looked so } \\
\text { good. } \\
\text { \#AANewBlue. }\end{array}$ \\
\hline
\end{tabular}

To conclude this results section, and to summarize, the first theme found in this data was the use of SCCT Response Strategies, with patterns that include the Diminish Strategy, bolstering, and scapegoating. Theme 2 is Care, and includes the use of insensitive incentives, delayed acknowledgment, and capital over care. Theme 3 is Misdirected Focus. These results will be interpreted and discussed in the following section.

\section{Chapter 5: Discussion}

Data analysis allowed for a start toward answering the research questions that guided this research. In summary, American Airlines did use some response strategies outlined in Situational Crisis Communication Theory. The deny strategy was used by scapegoating, the bolster strategy by bolstering the company's good deeds, and the diminish strategy by delaying acknowledgment. Whether or not these strategies were used ethically and with care in mind is subject to debate, but 
according to this thematic analysis, ethical attention to the landscape of care and ethics of care as

offered by the Applied Model of Care Considerations were not apparent in the company's communication via press releases and tweets during the first month of the COVID-19 pandemic. It is important to note, as mentioned in the case background and literature review, American Airlines is a major airline, not only in the United States, but globally. When a major company like American Airlines responds to a crisis or paracrisis, it lays the groundwork for smaller, lesser-known airlines to follow. The following section discusses the themes and patterns found in this thematic analysis and is followed by implications for both theory and practice.

\section{SCCT Response Strategies}

RQ1: How, if at all, did American Airlines' crisis communication response strategies during the first month of the COVID-19 pandemic reflect the response strategies defined in Situational Crisis Communication Theory?

American Airlines utilized the secondary crisis communication response strategy of bolstering, by promoting and highlighting themselves and their employees who were doing good deeds for the community on a national level. As stated in the literature, Coombs (2012) defines bolstering as "reminding stakeholders about the good works of the organization and/or how the organization is a victim as well" (p. 170). While this strategy did likely attempt to serve as a reminder to publics that American Airlines did indeed partake in good deeds, they failed to portray themselves as a negatively affected entity or many times even to acknowledge the overarching pandemic context of all communication. Some might argue that by bolstering their good image and insinuating customer care with other national concerns, American Airlines neglected to bolster their image and insinuate customer care with the Covid-19 global pandemic that was happening concurrently while their travel restrictions were being put into place. The 
data show that American Airlines neglected to mention the pandemic at all in many tweets and press releases, instead putting forth their good efforts in situations other than the global pandemic. This strategy could have led to a decrease in customer satisfaction and perceptions of company care, as those who had been directly impacted by American Airlines and their lack of response to the COVID-19 pandemic were now witness to fundraising in other areas to bolster the American Airline name and reputation. American Airlines bolstered in the wrong direction and could have created customer distrust and disinterest in their company. Perhaps a better strategy would have been to bolster their image by getting involved in fundraising efforts and customer care incentives concerning the coronavirus. This might have better fit Coombs' definition of bolstering good reputation and allowing themselves to be part of the solution to a problem to which inevitably, portrayed in this way or not, American Airlines is victim to.

A second pattern that is present in this data that pertains to the SCCT response strategies is that of scapegoating, which is a strategy used in many denial strategies (Coombs, 2012). American Airlines avoided naming the major factor (COVID-19 and related public health measures and restrictions) contributing to their initial decrease of sales and interest in travel and were perhaps attempting to "lighten" the situation by blaming it on issues such as changing priorities and general decreases in global travel. They were scapegoating, highlighting other factors (Coombs, 2012) that were related to COVID-19, but this fact was not acknowledged. It is possible that the company assumed that by not naming the (para)crisis at hand, it would quickly dissipate. Furthermore, and importantly, by scapegoating (i.e., placing the blame on someone or something else), American Airlines in effect relinquished its stronger ethical obligations to physically, humanly, politically/economically, and culturally care for their customer's emotional health and well-being, not in keeping with the Applied Model of Care Considerations. If one 
avoids responsibility for a crisis, then it may become easier for them also to avoid responsibility to care for those affected by the said crisis. When reading these data sources thoroughly, some missing response strategy pieces stood out. The addition of a "COVID-19 specific" boilerplate to every press release would have allowed the company to show they were taking the pandemic seriously and acknowledging the fact that it was affecting their customers and their business. This message could be something as simple as "American Airlines is working around the clock to assist you with travel-related needs. Should you need immediate health assistance, please call 911. We are committed to making this process as simple as possible for you during these trying times". The addition of this boiler plate, or acknowledgment in the companies' communication throughout March 2020, would have generously contributed to the fact that response strategies should be used to assist in diminishing and avoiding detrimental reputations. Their neglect in including these sorts of acknowledgments and sentiments confirms that there is an ethical gap in SCCT response strategy research and should be further explored.

\section{AMCC and Care}

RQ2: How, if at all, did American Airlines' crisis communication during the first month of the COVID-19 pandemic reflect the landscapes of care defined in the Applied Model of Care Considerations?

The fact that there was a six-week discrepancy between the high probability that American Airlines received valid information regarding the global pandemic, and their notification of the pandemic to their publics, exemplifies their extremely delayed acknowledgement of the crisis taking place, and perhaps their unwillingness to lose capital for the sake of their public's health and wellbeing. This could be viewed as a lack of ethics of care, 
defined in the AMCC. By refusing to properly name the main cause of the crisis, the company is diminishing its need to respond to and contribute to solving it for all involved.

Furthermore, as stated in the literature review portion of this work, the central focus of the ethics of care is on the compelling moral salience of attending to and meeting the needs of others for whom we take responsibility (Held, 2006). The delayed acknowledgment of the COVID-19 pandemic would be detrimental to the physical landscape of care defined in AMCC. People were stranded in foreign countries as a consequence of travel bans, customers were sick with COVID-19 symptoms, had no more money to spend, or a place to quarantine before flying home. The lack of preventative measures put into place by the airline, because of a lack of acknowledgment that a crisis was happening, shows that the airline did not take into consideration the Applied Model of Care Consideration or ethics of care in their crisis communication during the first month of the global pandemic.

The tenets of any crisis communication ethics of care are to be proactive, be transparent, and be accountable, with particular consideration for power disparities and vulnerability. This delayed acknowledgment is similar to that of United Airline's delayed acknowledgement of the negative press they received when a doctor was dragged off their flight and injured in the process to accommodate part of the flight crew in 2017 (Selk, 2017). The delayed acknowledgment confirms that there is a gap in care research surrounding crisis communication, and that not taking responsibility for, and punctually informing those we have taken responsibility for (our customers) can ultimately be detrimental to both the health and well-being of the customer and the reputation of a brand or organization.

Another theme that arose in this thematic analysis that pertains to ethics and the Applied Model of Care Consideration is that it appears that American Airlines was not fully sensitive to 
the potential needs of their customer base. By offering timed incentives to reschedule a trip, they neglected to consider that a large percentage of their customers required or preferred a full refund. The absence of an offer for a full refund makes the airline appear as though they did not have the publics' health and well-being in mind, and that they cared more about their finances. To emphasize this insensitive incentive pattern, within this data analysis, it became apparent that American Airlines did not have coping resources available during the COVID-19 pandemic. The organization did not assist in mitigating their customer's and consumers' stress and anxiety surrounding this crisis, which could be viewed as unethical and a blatant disregard for their customer's health and wellbeing (in addition to not following the directive from SCCT to first and foremost provide instructing and adjusting information before turning to reputational concerns).

As stated in the literature review portion of this work, care is the provision of practical or emotional support (Milligan \& Wiles, 2010), which American Airlines neglected in their communication response strategies. Instead of offering a waiving of change fees, the airline could have offered full refunds for those stranded, sick, or in any way affected by COVID-19. They might have relayed messaging about their mask mandates, their middle seat blocking, and their cleaning procedures, had there been any. Phone line assistance should have been increased for the duration of the crisis, and representatives should have worked with airports and other airlines to ensure that every passenger had the fastest route home for the price already paid. This pattern of insensitive incentives demonstrates that American Airlines was aware of the need for a landscape (offering of some sort of incentive) — but something more or different is needed for the ethical foundation in which the communication should have been grounded in. 
As stated in the literature review portion of this work, social media allows for the question to answer reciprocity, meaning that organizations can connect with and interact with their publics like never before. The ethic of care's focus on interdependence, mutuality, and reciprocity indeed mirror perspective on public relations (Coombs \& Holladay, 2013), so it is unsurprising that reciprocity is integrated into the AMCC. Ultimately, users can voice complaints vocally and publicly, and, in turn, pressure organizations to respond quickly because their complaints are on social media for other users to see. One would assume that American Airlines would use social media to their advantage, focusing on assisting their customers through this global pandemic and aiming to make the lives of those affected easier. As seen through the organizational responses to customer complaints and comments on Twitter, American Airlines did not exemplify ethics of care or any of the SCCT response strategies in their replies. Many of the replies used verbiage like "please check your DM" or, "We hear your complaint, please visit this website." These facts emphasize the need for future research to demonstrate a need for organizations to be prepared for a crisis and ethically communicate in a way that sensitively acknowledges the landscapes of care.

When examining this data, it became apparent that American Airlines did not take the financial/economic landscape of care into consideration. There was no mention in any of the press releases about hotel vouchers, overnight accommodations, or immediate assistance for changing a flight. Most of the press releases mentioned the fact that the decrease in flights was due to the decrease in travel demand or the decrease in customers, partially blaming the customers for the flight cancelations and rescheduling. There was no consideration of a global pandemic taking place, people losing jobs or childcare, or those unable to afford to travel to other locations. American Airlines appears to have attempted to take care of themselves, as a 
company, before taking care of the emotional health and wellbeing of their customers.

Additionally, concerning the ethics of care as a whole, American Airlines recorded a series of videos using spokespeople who mentioned caring about their customers but did not give any specifics as to how they would do that. Taking into consideration one of the cross-cutting foundations of the Applied Model of Care considerations, relationships, American Airlines could have used these spokespeople to create bonds and some sort of relationship with their vulnerable publics. "If we take this vulnerability as the anchor point for an ethic of care, there is no reason that a care ethic could not be applied to the public realm" (Vanacker \& Breslin, 2006, p. 204). Congruently, Steiner and Okrusch (2006, p. 108) affirmed that large-scale, actionable care ethics are possible and require "extending the world of moral consider ability well beyond local and family relationships." This pattern shows that there is a gap in research pertaining to delivering messages to publics via social media and press releases in an ethical, caring way.

It should also be mentioned that while one would assume that a major airlines' communication during a global pandemic with travel restrictions might be centered around healthcare and health-related resources, like where to find help if feeling sick, not a mention of any of these factors were present in the data examined. It should also be acknowledged that every response tweet that American Airlines sent redirected or asked the Twitter user asking them a question, to do another step or perform some sort of action to get an answer. Instead of answering the question or complaint in the response tweet, for others to see and acknowledge that the company was doing something to field complaints and make things right, American Airlines just asked users to DM them or "check their DM's" or call reservations on the phone to get an answer to their question. In terms of messaging strategies, the videos with the spokespeople for the company might have been more sincere and offered actual help for people, 
instead of promising to care for customers and employees and offering no help. The company could have provided a connection to mental health services for passengers who became too overwhelmed, or those who were going to visit sick family members. When a global health emergency was announced, American Airlines should have committed to communicating only about how the company was combating health-related things such as masks, social distancing, and cleaning, instead of bolstering the good deeds the company was taking part in that had nothing to do with the global pandemic taking place. Instead of sending out a heartfelt message about how the CARES Act would help the company stay on its feet, American Airlines probably would have generated more of a press buzz by highlighting the ways the company was giving back to communities greatly affected by the pandemic.

The pattern capital over care emerged from the "waiving change fees" announcements that were put out throughout March 2020 by American Airlines. The repetitive updates to the change fees the Airline promoted were the bare minimum of what could have been done for those stranded. The "waiving change fees" announcements were inadequate to successfully take care of their passenger's emotional and financial needs, and each announcement was a repetition of the last, with a few date changes. This pattern emerged from the lack of the word "refund" in the data, as well as not referring to the global pandemic by its name, but repetitively referring to COVID-19 as "the situation." As outlined above, American Airlines could have incorporated some of the landscapes of care and considered ethics of care in their communication. They might have considered the cultural landscape of care by realizing that the pandemic could disproportionately impact Latin Americans, African Americans, women, children, and many others. They should have considered the political/economic landscape by realizing that 2020 was an election year for the United States and that the pandemic caused people to lose their jobs, 
homes, businesses closed, and schools turned to remote learning, among other related items that would have a major economic impact in the short and long term. These political contexts increased sensitivity to any organizational activities perceived to capitalize monetarily in the midst of a global pandemic.

Furthermore, the airline could have considered the human landscape by realizing that their customers and potential customers are human, with fears and anxiety about the situation at hand. Being mindful of the various emotions that passengers and customers could have been feeling about travel at the beginning of a global pandemic should have been at the forefront of the organization's communication strategy. Lastly, the airline might have considered the physical landscape of care for those stranded in an airport because their flight was canceled without warning, or their flight was rescheduled and they were not given proper amenities, and they couldn't afford to stay in a hotel. Also, the airline should have taken into consideration the physical state of the person/customer in the current global pandemic. While some communication, for example the press release and tweets regarding the air filtration, did consider some of the physical realities of those flying during the pandemic, it did not conclude with any notions of care or ethical responses specific to the passenger's emotional health and wellbeing, and it also seemed short and succinct, with no notion to how a passenger or customer would be physically or mentally considered, but instead focused on how the air filtration system was "nothing new" for the airline.

\section{Theme 3}

The lack of media focus from American Airlines on the pressing issue of the COVID-19 pandemic, and their ensuing focus on other issues, such as new uniforms and women's history month, could create a detrimental effect on customer trust and appreciation for the company. The 
customer could feel that their current crisis was not being handled with as much gravity as it deserved. This lack of focus could also be seen as a diminished strategy because the airline could be trying to "diminish" or minimize organizational responsibility for the crisis by focusing on other company incentives, or it could be seen as a lack of ethics of care, because avoiding acknowledgement of a situation does not generally facilitate providing satisfactory care toward those affected. This pattern could also be its response strategy. Not acknowledging a crisis is a form of response. Coombs considers silence as a strategy, stating that "silence is too passive and allows others to control the crisis" (Coombs and Holladay, 2012). Perhaps American Airlines assumed if COVID-19 was not addressed in their communication in the first month, the (para)crisis would blow over and be ultimately averted.

While American Airlines does not appear to have handled the situation appropriately in their first month's communication regarding the coronavirus, the company did put out information regarding the virus after the $5^{\text {th }}$ day of March—regardless of how helpful that information may have been. Furthermore, no qualitative data came from interviews or firstperson discussions with those on the delivering or receiving end of this information, so assumptions cannot be made that private phone calls did not take place and additional information was not shared. With that being said, American Airlines is a large organization with many customers and potential customers, and one would think that an airline with a past crisis history would have integrated learning regarding the need for publicizing the help and care they are giving to their customers during trying times.

\section{Theoretical Implications}

To answer the research questions outlined in this work, American Airlines did use some response strategies outlined in the Situational Crisis Communication Theory and showed a lack 
of attention to all landscapes and most cross-cutting considerations in the Applied Model of Care Considerations. American Airlines used both the diminish and scapegoating strategy, as well as the secondary strategy of bolstering. As outlined in the literature, SCCT is often used to save a company's reputation instead of offering help to those affected by the crisis at hand, and that was true in this instance. American Airlines used these SCCT strategies to try and repair their reputation in their communication response, instead of offering help and emotional support to those who needed it most, their customers and those impacted by the global shared crisis. The lack of instructing and adjusting information to provide publics with information for physically and psychologically coping with the crisis was a violation of first tenets of SCCT as well as ethical obligations put forth by the AMCC. This research highlights the fact that there is a gap in research, and a need for further research pertaining to ethical crisis communication, particularly research that applies and expands the AMCC to incorporate more feminist and care-based perspectives to crisis public relations.

In summary, the findings from this study provide empirical support that organizations do use response strategies outlined in the Situational Crisis Communication theory, but we can conclude that further study of the SCCT and the AMCC needed to fully understand why and how ethical airline crisis communication is best enacted to both preserve and protect people and relationships while attending to reputational concerns as well. Research that expands the first tenets of the SCCT framework, instructing and adjusting information, to incorporate a fuller consideration of landscapes of care through the AMCC framework could significantly contribute to a better understanding and execution of ethical communication by organizations before, during, and after crises and paracrises.

\section{Implications for practice}


For practitioners managing crisis communication, an ethical response approach that considers the full spectrum of socio-cultural, relational, and environmental concerns in which communication occurs, instead of one that prioritizes the organizations reputation is called for. Outreach to increase education and awareness of how to synthesize abstract feminist normative philosophies in applies manners in public relations settings, as is offered by the AMCC, is warranted. Ultimately, organizations that more carefully acknowledge their power imbalances and attend to their relationships, especially with vulnerable or marginalized others, will judge crisis situations more compassionately and equitably, which translates into trust and perceived legitimacy.

Organizations that take crisis risks seriously would have to perform continuous monitoring of the publics' emotions and well-being before, during, and after a crisis, as well as organization-related information. An ongoing crisis then has also to be analyzed with regard to the feelings, the relationships, and the vulnerability of the publics in order to assess whether communication is addressing all landscapes of care to reach and maintain relationships with the target audience. On this basis, crisis managers could verify different options to influence ethical communication by emphasizing or underemphasizing human, physical, cultural, and political/economic landscapes of care and how the organization plans to assist those who are affected. After taking into consideration those who may be affected by said crisis, and understanding the contextually relevant landscapes of care, the organization can readjust their ethical crisis responsibility and employ crisis response strategies as suggested by Situational Crisis Communication Theory.

Future research should take a deeper dive into American Airlines' response strategy and aim to conduct qualitative interviews with staff and customers regarding communication from 
American Airlines in the form of press releases and tweets in March 2020. This would allow for American Airlines to explain their actions and provide insight into their underlying reasoning, explaining whether they thought what they were doing was sufficient and why, and will also allow for further research into the extent to which communication like emails and phone calls were taking place outside of the public communication sphere and either mirroring or diverging from that more public messaging. Based on the findings in this study, American Airlines did not appear to take the Applied Model of Care Considerations, ethics of care, or the landscapes of care into consideration when communicating with their publics during March 2020. Data showed patterns of communication across press releases and tweets wherein American Airlines revealed greater concerned for themselves than publics and worried about capital over care. No refunds were given, no hotel vouchers were given, no counseling was offered, no assistance was provided. Processes were not made easier for customers to make flight changes, announcements were copied and pasted into many press releases and tweets, and no care was shown in the replies from American Airlines on Twitter. The company responded to minute amounts of people asking for help in Twitter replies, and were very vague in their responses, asking users to "DM them about their problem" instead of offering immediate assistance for others to view.

\section{Limitations}

All methods have inherent limitations. The research landscape tends to be scattered with judgments about which type of research method is superior (Miles \& Huberman, 1994). Single case study analysis has been subject to several criticisms, the most common of which concern the inter-related issues of methodological rigor, researcher subjectivity, and external validity (Yin, 2009). The absence of systematic procedures for case study research is something that Yin (2009) sees as traditionally the greatest concern due to a relative absence of methodological 
guidelines. Since case studies rely on inductive reasoning to gain transferability from the examined data, researchers do not always value case study designs (Yin, 2009). Additionally, some researchers believe that case selection may alternatively lead to overgeneralization and/or grievous misunderstandings of the relationship between variables or processes (Bennett \& Elman, 2006). For example, the case study method did not enable me to fully develop an airline crisis communication plan or make medical claims about why caring about customers' emotional health is important. Although this research did not sentimentally analyze consumer tweets, future research should look at audience perspective.

Additionally, even with the most careful sampling, Twitter's data can be skewed. For instance, automated bots can accidentally be over-represented in the data samples or be invisible. Twitter, tweets, and press releases can also show the author's bias. Due to the lack of available crawled data, this study was unable to access the social media data of American Airlines on Instagram and Facebook. Instagram is primarily an image-sharing platform, which would presumably have different impression management tactics embedded as compared to Twitter. Similarly, Facebook differs from Twitter because it does not have a 280 -character limit, which means messaging on this platform may vary. Although this research did not sentimentally analyze consumer tweets, future research should look at the audience's perspective concerning the organizational crisis.

However, this work allowed the researcher to explore an area of crisis communication that is seldom researched and written about, apply and potentially build on a newer ethics model, as well as provide findings to future airline crisis communication researchers and practitioners. The hope is that eventually, the subject of ethical airline crisis communication becomes one of importance both in academic scholarship and industry practice. 


\section{Chapter 6: Conclusion}

To conclude, this work has endeavored to address three major gaps in crisis communication literature pertaining to: (1) lack of care in crisis communication, (2) lack of theory-based applied ethics in crisis communications and (3) lack of theory-based response strategies in crisis communications using a care lens. To address these limitations in extant scholarship, research presented the framework for the AMCC and SCCT for ethical and effective strategic communications strategies domestically and globally in the context of ethical airline communication. This research is valuable because there is a lack of crisis communication research concerning emotion and ethics in crisis communication research, as well as a lack of airline crisis communication research. This research is a fundamental step in examining how airline communication exhibits a lack of ethics and setting a basis for recommendations that integrate feminist-oriented ethical perspectives for applied settings in the airline organizationpublic relational context. For major organizations to ignore or minimize publics' emotions and wellbeing in their communication in connection to their operations and public services is doing an injustice to their customers and to society. It is the hope that this timely and relevant research, given our current situation and the global pandemic in which we are all involved, contributes to future research and assists in creating ethical, strategic crisis communication for airlines, their publics, and our society moving forward. 


\section{References}

American Airlines. (n.d.). Newsroom - home - American Airlines Group, Inc. Retrieved February 19, 2021, from http://news.aa.com/home/default.aspx

An, S., \& Cheng, I. (2010). Crisis communication research in public relations journals: Tracking research trends over thirty years. In W. T. Coombs \& S. J. Holladay (Eds.), The handbook of crisis communication (pp. 65-90). Malden, MA: Wiley- Blackwell.

Aten, J. (2020, June 28). United and American airlines are making customers angry with this change. Retrieved February 19, 2021, from https://www.inc.com/jason-aten/unitedamerican-airlines-are-making-customers-angry-with-this-change.html

Austin, L., \& Jin, Y. (2015). Approaching ethical crisis communication with accuracy and sensitivity: Exploring common ground and gaps between journalism and public relations. Public Relations Journal, 9(1), 2.

Avery, E. J., Lariscy, R. W., Kim, S., \& Hocke, T. (2010). A quantitative review of crisis communication research in public relations from 1991 to 2009. Public Relations Review, 36(2), 190-192. https://doi.org/10.1016/j.pubrev.2010.01.001

Banerjee, S. B. (2008). Corporate social responsibility: The good, the bad and the ugly. Critical Sociology, 34(1), pp. 51-79. doi: 10.1177/0896920507084623

Barrett, L. F. (2017). How Emotions Are Made: The secret life of the brain. S.1.: Picador.

Beaumont, C. (2008), Mumbai Attacks: Twitter and Flickr used to Break News, http://www.telegraph.co.uk/news/worldnews/asia/india/3530640/Mumbai-attacks Twitter-andFlickr-used-to-break-news-Bombay-India.html

Bennett, A., and C. Elman. 2006. Qualitative research: Recent developments in case study methods. Annual Review of Political Science 9: 455-476.

Benoit, W. L. (1997). Image repair discourse and crisis communication. Public relations review, 23(2), 177-186.https://doi.org/10.1016/S0363-8111(97)90023-0

Berge, T. (1990). The First 24-Hours. Cambridge, MA: Basil Blackwell, Inc.

Bernstein, J. (2011). Manager's Guide to Crisis Management, McGraw-Hill

Bogdan, R. C., \& Biklen, S. K. (2003). Qualitative research for education: An introduction to theories and methods (4th ed.). New York, NY: Pearson Education Group.

Boyatzis, RE 1998, Transforming Qualitative Information: Thematic Analysis and code development, Thousand Oaks, SAGE Publications. 
Braun, V., \& Clarke, V. (2006). Using thematic analysis in psychology. Qualitative Research in Psychology, 3(2), 77-101. https://doi.org/10.1191/1478088706qp063oa

Callahan, J. C. (1988). Ethical issues in professional life. Oxford University Press.

Callison, C., \& Seltzer, T. (2010). Influence of responsiveness, accessibility, and professionalism on journalists' perceptions of Southwest Airlines public relations. Public Relations Review, 36(2), 141-146. https://doi.org/10.1016/j.pubrev.2010.01.002

CDC. (2020). Coronavirus Disease 2019 (COVID-19). Retrieved October 05, 2020, from https://www.cdc.gov/coronavirus/2019-ncov/index.html

Chao, R. C. L. (2011). Managing stress and maintaining well-being: Social support, problem-focused coping, and avoidant coping. Journal of Counseling \& Development, 89(3), 338-348. https://doi.org/10.1002/j.1556-6678.2011.tb00098.x

Chyi, H. I., \& McCombs, M. (2004). Media salience and the process of framing: Coverage of the Columbine school shootings. Journalism \& Mass Communication Quarterly, 81(1), 2235.

Chokshi, N. (2020, May 10). The airline business is Terrible. it will probably get even worse. Retrieved February 19, 2021, from https://www.nytimes.com/2020/05/10/business/airlinescoronavirus-bleak-future.html

Chong, M. The Role of Internal Communication and Training in Infusing Corporate Values and Delivering Brand Promise: Singapore Airlines' Experience. Corp Reputation Rev 10, 201-212 (2007). https://doi.org/10.1057/palgrave.crr.1550051

Coombs, W. Protecting Organization Reputations During a Crisis: The Development and Application of Situational Crisis Communication Theory. Corp Reputation Rev 10, 163176 (2007). https://doi.org/10.1057/palgrave.crr.1550049

Coombs, W. T. (2014). Ongoing crisis communication: Planning, managing, and responding. Sage Publications.

Coombs, W. T. (2007). Protecting organization reputations during a crisis: The development and application of situational crisis communication theory. Corporate reputation review, 10(3), 163-176. https://doi.org/10.1057/palgrave.crr.1550049

Coombs, W. T., \& Holladay, J. S. (2012). The paracrisis: The challenges created by publicly managing crisis prevention. Public Relations Review, 38(3), 408-415. https://doi.org/10.1016/j.pubrev.2012.04.004

Coombs, W. T., \& Holladay, S. J. (2013). It's not just PR: Public relations in society. Malden, MA: Wiley-Blackwell. 
Corbin, J., \& Strauss, A. (2008). Basics of qualitative research: Techniques and procedures for developing grounded theory. Sage.

Daly, M., \& Lewis, J. (2000). The concept of social care and the analysis of contemporary welfare states. The British journal of sociology, 51(2), 281-298. https://doi.org/10.1111/j.1468-4446.2000.00281.x

Darling, J., Seristo, H., \& Gabrielsson, M. (2005). Anatomy of crisis management: a case focusing on a major cross-cultural clash within DaimlerChrysler. Liiketaloudellinen aikakauskirja, 3, 343. 1ta.lib.aalto.fi

Denzin, N. K., \& Lincoln, Y. S. (2003). The landscape of qualitative research: Theories and issues (2nd ed.). Thousand Oaks, CA: Sage.

Duhachek, A. (2005). Coping: A multidimensional, hierarchical framework of responses to stressful consumption episodes. Journal of Consumer Research, 32(1), 41-53. doi: $10.1086 / 426612$

Ekman P. (1999). "Basic emotions," in Handbook of Cognition and Emotion, eds Dalgleish T.,

Power M. J. (New York, NY: John Wiley \& Sons Ltd; ), 45-60.

Esterberg, K. G. (2002). Qualitative methods in social research. Boston, MA: McGraw-Hill.

Faulkner, B. (2001). Towards a framework for tourism disaster management. Tourism management, 22(2), 135-147.

Fearn-Banks, K. (2017). Crisis communications: A casebook approach. New York, N.Y: Routledge.

Finfgeld-Connett, D. (2015). Twitter and health science research. Western Journal of Nursing Research, 37, 1269-1283 15p. doi:10.1177/0193945914565056

Fein, M. (2013, May 03). American airlines Celebrates 80 years of flight attendants. Retrieved February 19, 2021, from https://www.nbcdfw.com/news/local/american-airlinescelebrates-80-years-of-flight-attendants/2092338/

Fraustino, J. D., \& Kennedy, A. K. (2018). Care in crisis: an applied model of care considerations for ethical strategic communication. The Journal of Public Interest Communications, 2(1), 18-18. https://doi.org/10.32473/jpic.v2.i1.p18

Fraustino, J. D., \& Liu, B. F. (2017). Toward more audience-oriented approaches to crisis communication and social media research. In L. Austin \& Y. Jin (Eds.), Social media and crisis communication (pp. 82-129). New York, NY: Routledge. 
Fereday, J \& Muir-Cochrane, E 2006, "Demonstrating rigor using thematic analysis: A hybrid approach of inductive and deductive coding and theme development", International Journal of Qualitative Methods, vol. 5, no. 1, pp. 80-92.

Gibbs, G. R. (2007). Thematic coding and categorizing. Analyzing qualitative data, 703, 38-56.

Gilligan, C. (1982). In a different voice. Cambridge, MA: Harvard University Press. Doi: 10.1111/j.1471-6402.1985.tb00902.x

Golafshani, N. (2003). Understanding reliability and validity in qualitative research. The qualitative report, 8(4), 597-607. Retrieved from https://nsuworks.nova.edu/tqr/vol8/iss $4 / 6$

Glusac, E. (2020, July 21). Worried about crowded planes? Know where your airline stands. Retrieved February 19, 2021, from https://www.nytimes.com/2020/07/21/travel/crowdedflights-coronavirus.html

Greer, C. F., \& Moreland, K. D. (2003). United Airlines' and American Airlines' online crisis communication following the September 11 terrorist attacks. Public relations review, 29(4), 427-441. https://doi.org/10.1016/j.pubrev.2003.08.005

Grunig, James \& Hunt, Todd. (1984). Managing Public Relations.

Grunig, L. A., Toth, E. L., \& Hon, L. C. (2000). Feminist values in public relations. Journal of Public Relations Research, 12(1), 49-68.https://doi.org/10.1207/S1532754XJPRR1201_4

Hammarberg, K., Kirkman, M., de Lacey, S., Qualitative research methods: when to use them and how to judge them, Human Reproduction, Volume 31, Issue 3, March 2016, Pages 498-501, https://doi.org/10.1093/humrep/dev334

Held, V. (2006). The ethics of care: Personal, political, global. Oxford: Oxford University Press. doi:10.1093/0195180992.001.0001

Hiscott, John et al. "The global impact of the coronavirus pandemic." Cytokine \& growth factor reviews vol. 53 (2020): 1-9. doi:10.1016/j.cytogfr.2020.05.010

Holger, H., \& Sebastian, H. (2003). Airline strategy in the 2001/2002 crisis - the Lufthansa example. Journal of Air Transport Management, 9(1), 51-55. doi:https://doi.org/10.1016/S0969-6997(02)00064-9.

Hughes, A. L., Palen, L., Sutton, J., Liu, S. B., \& Vieweg, S. (2008, May). Site-seeing in disaster: An examination of on-line social convergence. In Proceedings of the 5 th International ISCRAM Conference (pp. 44-54). Washington, D.C.

Hyde, KF 2000, "Recognising deductive processes in qualitative research", Qualitative Market Research: An International Journal, vol. 3, no. 2, pp. 82-90. 
Incredible industrial exoskeletons. (2020). Retrieved November 09, 2020, from http://www.boeing.com/

Institute for Public Relations. (2019, November 01). Retrieved November 09, 2020, from https://instituteforpr.org/

International Air Transport Association. (n.d.). Retrieved February 19, 2021, from https://www.iata.org/en/pressroom/searchresults/?archivecontent $=$ true $\&$ Search $=$ American + Airlines $\&$ ContentType $=85 \&$ Region $=134 \&$ ordering $=$ Rel evance

Jeff Stein, L. (2020, March 03). Major airlines, U.S. Officials clash over passenger tracking related to coronavirus CASES. Retrieved February 19, 2021, from https://www.washingtonpost.com/business/2020/03/02/airline-data-cdc-coronavirus/

Jin, Y., Pang, A., \& Cameron, G. T. (2012). Toward a publics-driven, emotion-based conceptualization in crisis communication: Unearthing dominant emotions in multistaged testing of the Integrated Crisis Mapping (ICM) model. Journal of Public Relations Research, 24, 266-298. doi:10.1080/1062726X.2012.676747

Kamil, A. Role of Public Relations in Crisis Management with the Coronavirus Crisis as an Example: A Case Study on the UAE. Global Media Journal 2020, 18:35.

Kim, Y. (2015). Toward an ethical model of effective crisis communication. Business and Society Review, 120(1), 57-81.

Kitroeff, N., \& Silver-Greenberg, J. (2020, March 31). Airlines refused to COLLECT passenger data that could Aid coronavirus fight. Retrieved February 19, 2021, from https://www.nytimes.com/2020/03/31/business/coronavirus-airlines-contact-tracing$\underline{\text { cdc.html }}$

Lachlan K., Spence P., Eith C. (2014) Risk, Crisis, and Emergency Communication in Developing Countries: Identifying the Needs of Urban Populations. In: Okigbo C. (eds) Strategic Urban Health Communication. Springer, New York, NY. https://doi.org/10.1007/978-1-4614-9335-8_6

Lazarus, R. S. (1991). Emotion and adaption. New York, NY: Oxford University Press.

Lenhart, P. (2009), Twitterpated: Mobile Americans Increasingly Take to Tweeting, Pew Research Center Publications, http://www.pewresearch.org/pubs/1117/twitter-tweetusers-demographics

Li, F., Larimo, J. \& Leonidou, L.C. Social media marketing strategy: definition, conceptualization, taxonomy, validation, and future agenda. J. of the Acad. Mark. Sci. (2020). https://doi.org/10.1007/s11747-020-00733-3 
Liu, B. F., \& Fraustino, J. D. (2014). Beyond image repair: Suggestions for crisis communication theory development. Public Relations Review, 40(3), 543-546.

Luborsky, M. R. (1994). The identification and analysis of themes and patterns. In J. F. Gubrium \& A. Sankar (Eds.), Sage focus edition, Vol. 168.

Majumder, M. (2020, January 24). If you're posting your research on Twitter, please provide enough context for the average reader. Retrieved February 18, 2021 from https://witter.com/maiamajumder/status/1220924221536325633. Accessed 26 January 2020.

Makau, Josina M. "Ethical and Unethical Communication." 21st Century Communication: A Reference Handbook. Ed. Thousand Oaks, CA: SAGE, 2009. 433-44. SAGE Reference Online. Web. 2 Jul. 2012.

Merriam, S. (1988). Case study research in education: A qualitative approach. San Francisco: Jossey Bass.

Milligan, C., \& Wiles, J. (2010). Landscapes of care. Progress of Human Geography, 34(6), 736-754.

Morland, J. \& Feagin, Joe \& Orum, Anthony \& Sjoberg, Gideon. (1992). A Case for the Case Study. Social Forces. 71. 240. 10.2307/2579984.

New America Media (2011). 'Social Media Made Tunisian Uprising Possible', New America Media, http://newamericamedia.org/2011/01/social-media-made-tunisian-uprising-possible.php

Noddings, N. (1984). Caring, a feminine approach to ethics and moral education. Berkeley, CA: University of California Press.

O’Connor, A., Jackson, L., Goldsmith, L., Skirton, H. (2014). Can I get a retweetplease? Health research recruitment and the Twittersphere. Journal of Advanced Nursing, 70, 599-609. doi:10.1111/jan.12222

Parsons, P. (2004). Ethics in public relations: A guide to best practice. London, United Kingdom: Kogan Page Limited.

Patton, M. Q. (1987). How to use qualitative methods in evaluation (2nd ed.). Newbury Park, CA: Sage.

Pinsdorf, M. K. (1991). Flying different skies: How cultures respond to airline disasters. Public Relations Review, 17(1), 37-56. https://doi.org/10.1016/0363-8111(91)90005-6

Pollett, S. \& Rivers, C. (2020, October 15). Social Media and the New World of Scientific Communication During the COVID-19 Pandemic, Clinical Infectious Diseases, Volume 71, Issue 16, 15 Pages 2184-2186, https://doi.org/10.1093/cid/ciaa553 
Pope, C., \& Mays, N. BMJ books London; UK: 1999. Qualitative research in health care.

PRSA: Public Relations Society of America. (n.d.). Retrieved November 09, 2020, from https://www.prsa.org/home

Robinson, E. (2010), 'Following the Earthquake in Haiti on Twitter', Washington Post, 13 January, http://voices.washingtonpost.com/postpartisan/2010/01/following the earthquake in ha.html

Ryan, G. W., \& Bernard, H. R. (2003). Techniques to Identify Themes. Field Methods, 15(1), 85-109. https://doi.org/10.1177/1525822X02239569

Salas, G. (2020, November 30). The pandemic is disproportionately affecting women - here's why. Retrieved February 09, 2021, from https://nwhn.org/the-pandemic-is-disproportionately-affecting-women-heres-why/

Saldana, J. M. (2015). The coding manual for qualitative researchers (3rd ed.). SAGE Publications.

Salzmann-Erikson, M. (2017). Virtual communication about psychiatric intensive care units: Social actor representatives claim space on Twitter. International Journal of Mental Health Nursing, 26, 366-374. doi:10.1111/inm.12253

Seidman, I. (1998). Interviewing as qualitative research: a guide for researchers in education and the social sciences. United Kingdom: Teachers College Press.

Seitel, F. 2007. The Practice of Public Relations, 10th ed. Upper Saddle River, NJ: Prentice Hall.

Sellnow, T. L., Ulmer, R. R., Seeger, M. W., \& Littlefield, R. (2008). Effective risk Communication: A message-centered approach. Springer Science \& Business Media.

Selk, A. (2019, April 05). A man wouldn't leave an overbooked United flight. So he was dragged off, battered and limp. Retrieved April 20, 2021, from https://www.washingtonpost.com/news/dr-gridlock/wp/2017/04/10/a-man-wouldntleave-an-overbooked-united-flight-so-he-was-dragged-off-battered-andlimp/?hpid=hp_hp-more-top-stories_gridlock-united-1115am\%3Ahomepage\%2Fstory

Sevenhuijsen, S. (2000). Caring in the third way: the relation between obligation, responsibility and care in Third Way discourse. Critical Social Policy, 20(1), 5-37. https://doi.org/10.1177/026101830002000102

Silk, J. (2000). The big bang. Macmillan.

Singh, J. (2019, April 01). The story of American airlines - how the airline is what it is today. Retrieved February 19, 2021, from https://simpleflying.com/american-airlines-history/ 
Skærbaek, E. (2011). Navigating in the landscape of care: A critical reflection on theory and practice of care and ethics. Journal of Health Philosophy and policy, 19(1), 41-50. doi: $10.1007 / \mathrm{s} 10728-010-0157-5$

Smith, B.G. (2010b). 'Socially Distributing Public Relations: Twitter, Haiti, and Interactivity in Social Media', Public Relations Review, Volume 36, Number 4, pp. 329- 335.

Spence, J. T., \& Helmreich, R. L. (1980). Masculine instrumentality and feminine expressiveness: Their relationships with sex role attitudes and behaviors. Psychology of Women Quarterly, 5(2), 147-163. https://doi.org/10.1111/j.1471-6402.1980.tb00951.x

Stake, R. E. (1995). The art of case study research. Sage publications.

Strauss, A., \& Corbin, J. (1998). Basics of qualitative research: Techniques and procedures for developing grounded theory (2nd ed.). Thousand Oaks, CA: Sage.

Stump, T., Zilch, S., Coustasse, A. (2012). The emergence and potential impact of medicine 2.0 in the health-care industry. Hospital Topics, 90, 33-38.

doi:10.1080/00185868.2012.679909

Sutton, J., Palen, L. and Shklovski, I. (2008), Backchannels on the Front Lines: Emergent Uses of Social Media in the 2007 Southern California Wildfires, Proceedings of the 5th International ISCRAM Conference, May, Washington, DC, pp. 1-9.

Telang, A., \& Deshpande, A. (2016). Keep calm and carry on: A crisis communication study of Cadbury and McDonalds. Management \& Marketing. Challenges for the Knowledge Society, 11(1), 371-379. DOI: 10.1515/mmcks-2016-0003.

The Associated Press. (1993, August 04). Eight Enter Guilty Pleas, Most Face Prison Time With AM-OutFront-Pepsi Pursuit. Retrieved November 21, 2020, from https://apnews.com/article/c33a035e2a5bd245d6cc5aa133ceb5a4

Tronto, J. C. (1993). Moral boundaries: A political argument for an ethic of care. Psychology Press.

TSA to implement executive order Regarding face masks in the transportation system. (n.d.). Retrieved February 19, 2021, from https://www.tsa.gov/

Turk, J. V., Jin, Y., Stewart, S., Kim, J., \& Hipple, J. R. (2012). Examining the interplay of an organization's prior reputation, CEO's visibility, and immediate response to a crisis. Public Relations Review, 38(4), 574-583.

Vanacker B., \& Breslin, J. (2006). Ethics of care: More than just another tool to bash the media? Journal of Mass Media Ethics, 21(2/3): 196-214.

Veatch, R. M. (1998). The place of care in ethical theory. The Journal of medicine and philosophy, 23(2), 210-224. 
Viswanath K, Nagler RH, Bigman-Galimore CA, McCauley MP, Jung M, Ramanadhan S. The communications revolution and health inequalities in the 21 st century: Implications for cancer control. Cancer Epidemiology, Biomarkers, and Prevention. 2012;21(10):1701-1708.

WHO. (2020). Retrieved November 15, 2020, from https://www.who.int/

World Business Council. 2005. "Corporate Social Responsibility.” Retrieved May 31, 2005. (http://www. Partnerships.gov.au/csr/corporate.shtml).

Yin, R. K. (2017). Case study research and applications: Design and methods. Sage publications.

Yin, R. K. (2009). Case study research: Design \& methods. Thousand Oaks, CA: Sage Publishing.

Yin,R. K. (1994). Discovering the future of the case study. Method in evaluation Research. Evaluation practice, 15(3), 283-290.

Yin, R. K. (2002). Case study research: Design and methods. Thousand Oaks, CA: SAGE Publications.

Zafra, N., \& Maydell, E. (2018). Facing the information void: A case study of Malaysia Airlines' media relations and crisis communication during the MH370 disaster. Asia Pacific Public Relations Journal, 19, 41-65. 
Appendix A

\begin{tabular}{|c|c|}
\hline Key Term & Definition \\
\hline Attack the accuser & $\begin{array}{l}\text { crisis manager confronts the person or group } \\
\text { claiming something is wrong with the } \\
\text { organization. }\end{array}$ \\
\hline Denial & $\begin{array}{l}\text { crisis manager asserts that there is no crisis, } \\
\text { changes subject }\end{array}$ \\
\hline Scapegoat & Blame someone/something else \\
\hline Excuse & $\begin{array}{l}\text { crisis manager minimizes organizational } \\
\text { responsibility by denying intent to do harm } \\
\text { and/or claiming inability to control the events } \\
\text { that triggered the crisis }\end{array}$ \\
\hline Provocation & $\begin{array}{l}\text { crisis was a result of response to someone } \\
\text { else's actions }\end{array}$ \\
\hline Defeasibility & $\begin{array}{l}\text { lack of information about events leading to } \\
\text { the crisis situation }\end{array}$ \\
\hline Accidental & $\begin{array}{l}\text { lack of control over events leading to the } \\
\text { crisis situation }\end{array}$ \\
\hline Good intentions & organization meant to do well \\
\hline Justification & $\begin{array}{l}\text { Crisis manager minimizes the perceived } \\
\text { damage caused by the crisis, reaffirm a crisis } \\
\text { situation as residing in the accidental cluster, } \\
\text { lessen attributions of crisis responsibility }\end{array}$ \\
\hline Compensation & providing regular updates on the situation \\
\hline Apology strategies & $\begin{array}{l}\text { help change perceptions of an organization } \\
\text { during a crisis by offering real or symbolic } \\
\text { forms of aid to victims and asking their } \\
\text { forgiveness. These strategies attempt to take } \\
\text { the focus off the crisis by taking positive } \\
\text { action }\end{array}$ \\
\hline Ingratiation & $\begin{array}{l}\text { crisis manager praises stakeholders for their } \\
\text { actions, uses spokesperson }\end{array}$ \\
\hline Victimage & $\begin{array}{l}\text { can be used as part of the response for } \\
\text { workplace violence, product tampering, } \\
\text { natural disasters and rumors }\end{array}$ \\
\hline Informing & $\begin{array}{l}\text { inform team about crisis and identify a } \\
\text { spokesperson, Inform public about crisis in } \\
\text { respectable manner }\end{array}$ \\
\hline
\end{tabular}




\begin{tabular}{|l|l|}
\hline Adjusting & adjust information when needed \\
\hline Ethics of Care & Recognition of context \\
\hline Cultural Landscape & $\begin{array}{l}\text { race, gender roles, religion, sex, and social } \\
\text { norms }\end{array}$ \\
\hline Physical Landscape & $\begin{array}{l}\text { material resources, geography, and } \\
\text { technology }\end{array}$ \\
\hline Human Landscape & $\begin{array}{l}\text { emotions, health and wellbeing, educational } \\
\text { level, families, and networks, as well as } \\
\text { individual experience }\end{array}$ \\
\hline Political/Economic Landscape & $\begin{array}{l}\text { political censorship, the economic state of the } \\
\text { public, taxation, and international policies }\end{array}$ \\
\hline
\end{tabular}

Note: All variables, terms and definitions were drawn from the literature, most particularly Coombs $(2012,2007)$ and Fraustino and Kennedy (2018). 